\title{
Development of a Theoretical Model for the Definition Process of the Successful Mega- Program in Iran`s Free Zone
}

Hamzeh Saadat Gharehbagh ${ }^{1}$ Ph. D. Student, Department of Project Management, School of Art and Architecture, Tarbiat Modares University, Tehran, Iran.

Mohammad Hossein Sobhiyah ${ }^{2}$ Associate Professor, Department of Project Management, School of Art and Architecture, Tarbiat Modares University, Tehran, Iran (Corresponding Author).

Seyed Hamid Khodadad Hosseini ${ }^{3}$ Professor, Department of Business Administration, School of Management and Economics, Tarbiat Modares University, Tehran, Iran.

Hashem Dadashpoor ${ }^{4}$ Associate Professor, Department of Urban Planning, School of Art and Architecture, Tarbiat Modares University, Tehran, Iran.

\begin{abstract}
The growing popularity of free zone mega-programs has led to the need to study the success of these mega-programs; a topic that has not received enough attention in project management researches. The purpose of the present study is to develop a theoretical model for the definition process of successful free zone mega-programs in Iran. This study was conducted through an inductive approach and used the grounded theory strategy. For this purpose, data were first collected through semi-structured interviews with twenty-two private and public sector managers related to Iran's free zones. Then, data analysis was performed using coding techniques. The categories related to the definition process of successful free zone mega-programs in Iran were extracted from the interviews and relationships among the categories that were discussed. Based on the process of coding, six propositions were created and the theoretical model for definition process of successful free zone mega-programs was developed. Using the results of this study, the factors influencing the definition of a successful free zone mega-program as well as criteria for evaluating the success of the process of defining the free zone mega-program are presented.
\end{abstract}

Keywords: Grounded Theory, Free Zone Mega-program, Project Success, Program Definition Process, Success Factors, Success Criteria.

1.h.saadat@modares.ac.ir

2.sobhiyah@modares.ac.ir

3.khodadad@modares.ac.ir

4.h-dadashpoor@modares.ac.ir 


\section{عنوان مقاله: تدوين مدل نظرى فرايند تعريف ابرطرح موفق منطقه آزاد در ايران}

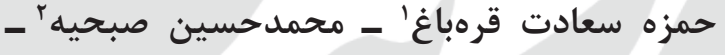

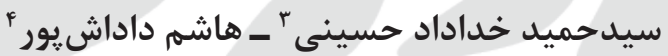

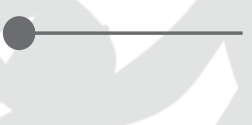

مقاله يزثوهشى

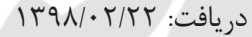

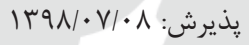
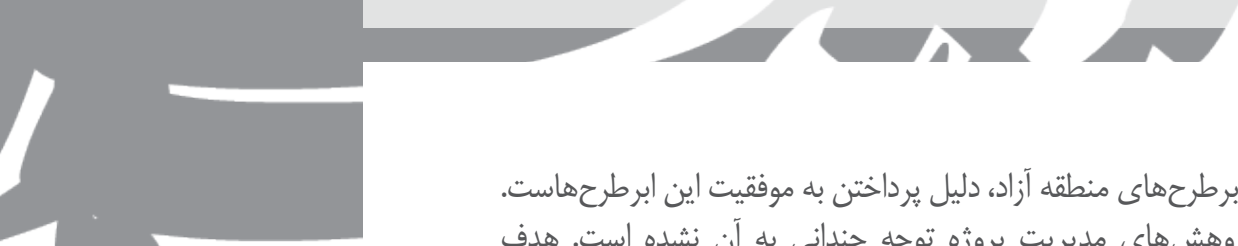

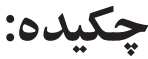

كَسترش روزافزون ابرطرحهاى منطقه آزاد، دليل يرداختن به موفقيت اين ابرطرحهاست.

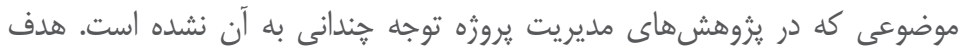

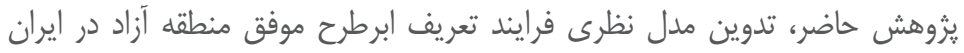

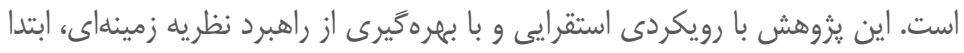

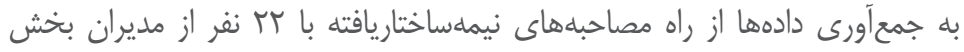

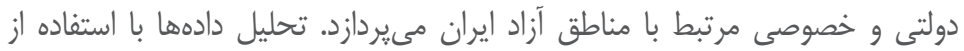

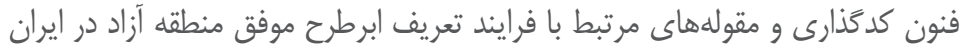

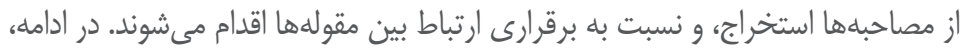

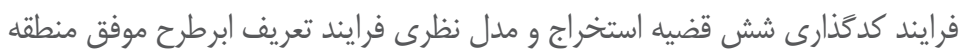

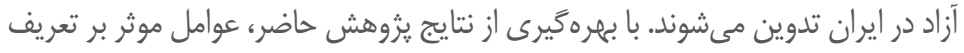

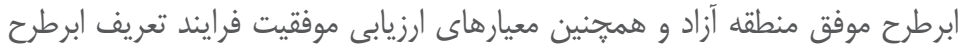
منطقه آزاد ارائه مى منىند.

كليدوازهها: نظريه زمينهاى، ابرطرح منطقه آزاد، موفقيت يروزمه، فرايند

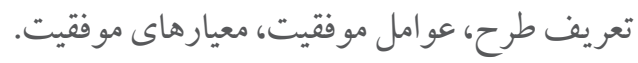

1. دانشجوى دكترى، كروه مديريت بروزةهو ساخت، دانشكده هنرو معمارى، دانشكاه تربيت مدرس، تهران،ايران. h.saadat@modares.ac.ir

r. دانشيار، گروه مديريت يروزهه و ساخت، دانشكده هنر و معمارى، دانشگاه تربيت مدرس، تهران، ايران (نويسنده

sobhiyah@modares.ac.ir

r. استاد، گروه مديريت بازر كانى، دانشكده مديريت و اقتصاد، دانشكاه تربيت مدرس، تهر ان، ايران. khodadad@modares.ac.ir h-dadashpoor@modares.ac.ir

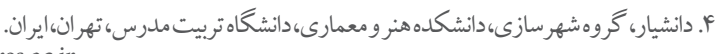




\section{مقدمه}

ابرطرحهاى منطقه آزاد' از جمله ابزارهاى مهرم توسعه هستند كه موفقيت 'آنها مىتواند باعث جلب سرمايه، انتقال فناورى، آموزش نيروى انسانى، تحصيل مديريت علمى، گسترش صادرات، ادغام كشور در بازار جهانى، و ايجاد دريجهاي به سوى توسعه اقتصادى گردد (ذاكرى و اسفنديارى،

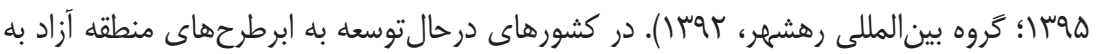
عنوان يك ابزار توانمند توسعه اقتصادى براى كل كشور نخريسته مى شود و نه يكى منطقله صرفاً تجارى (ميرحيدر، (وسا). ابرطرح منطقه آزاد ابزارى است كه به دور از ديوانسالارى حاكم بر

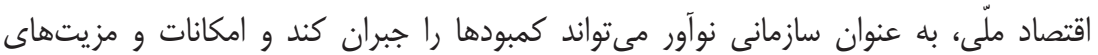
بالقوه را در سطح ملّى به توانايى بالفعل تبديل كند و يلى بين اقتصاد داخلى و اقتصاد جهانى شود

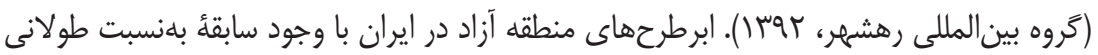

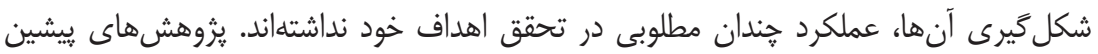

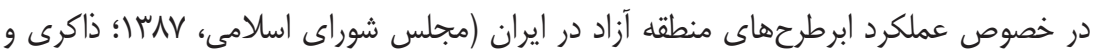

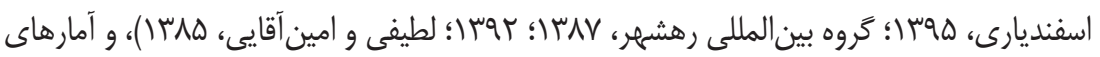
رسمى اعلامشده از سوى دبيرخانه شوراى عالى مناطق آزاد تجارى، صنعتى، و ويزه اقتصادى ايران

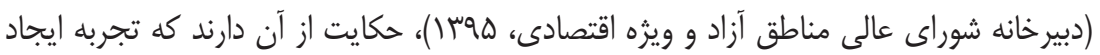
اين ابرطرحها به عنوان ابزارى براى توسعه كشور، تجربه جندان موفقى در مقايسه با تجربيات ساير

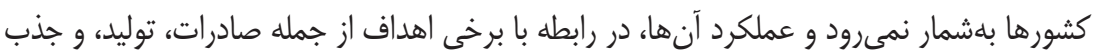
سرمايهگذارى خارجى، با دستاورد جندان قابلاعتنايى همراه نبوده است (جدول () (دبيرخانه شوراى

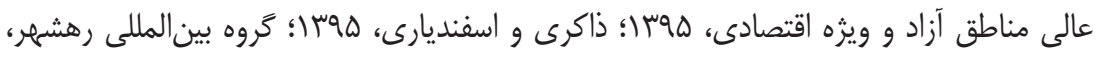

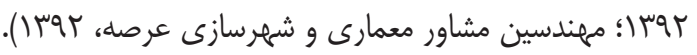


جدول 1: بررسى عملكرد ابرطرحهاى منطقه آزاد ايران با توجه به اهداف آنها (ذاكرى و اسفنديارى، هوساب)

\begin{tabular}{|c|c|c|}
\hline عملكرد & هدف & رديف \\
\hline 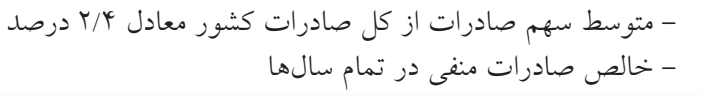 & توسعه صادرات & 1 \\
\hline - - اندى (متوسط ساليانه حدود ·ـ ب مليش مليون دلار) & جذب سرمايه كذارى خار. & r \\
\hline 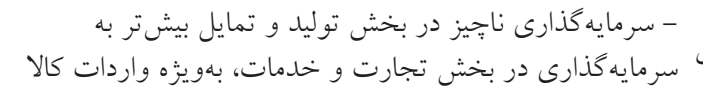 & جذب سرمايه كذارى داخلم & $r$ \\
\hline ت - سهم اندى از كل اشتغال كشور & ايجاد اشتغال و توسعه مهار, & r \\
\hline - نياز جدى به سرمايه كذارى در زيرساختها & سرمايه كذارى زيربنايى & 0 \\
\hline - سهم كم از بازار بين المللى ترانزيت كالا & ت ت ترانزيت كالا & 4 \\
\hline 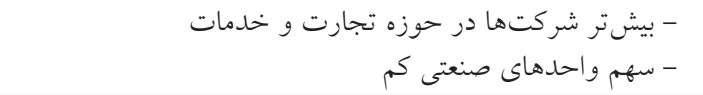 & شركتهاى ثبتشده & $\checkmark$ \\
\hline - سهم اندى در جذب كردشكر خارجى & كردشكرى & $\wedge$ \\
\hline
\end{tabular}

در يثروششهاى ييشين، به موضوع موفقيت ابرطرحهاى منطقه آزاد از منظرهاى مختلفى يرداخته

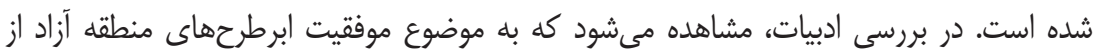
منظرهاى اقتصادى، سياسى، حقوقى، اجتماعى، توسعه منطقهاى، و تجارت بينالملل يرداخته مىشود Aggarwal, 2010; Auruškevičienè et al., 2007; Bell, 2016; Cling et al., 2005;) (Sosnovskikh, 2017; Tantri, 2015; Zeng, 2016 در هر كدام از اين نگاهها بخشى از اهداف و وظايف ابرطرح منطقه آزاد بررسى مىشوند و عوامل موفقيت' مرتبط با آن اهداف مورد شناسايى قرار مى گيرند. نكته جالب توجه در تمامى اين يثوهشها اين است كه در بيشتر آنها از منطقه

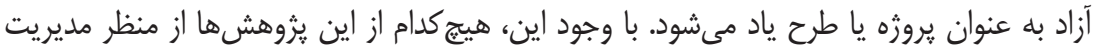

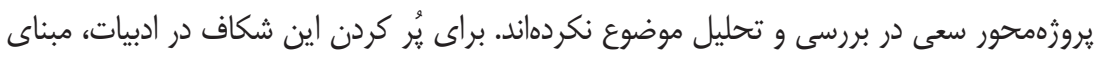
نظرى يزوهش حاضر تحليل موضوع از ديدكًاه مديريت يروزمهحور است (Turner, 2014). در

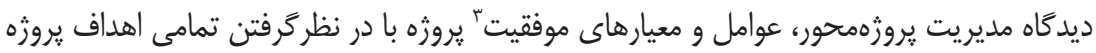
شناسايى و تحليل مىشوند.

1. Success Factors

2. Project Based Management

3. Success Criteria 
در بررسى بزوهشهاى مرتبط با موفقيت يروزه مشاهده مىشود كه در يزوهشهاى كلاسيك

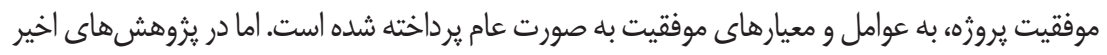

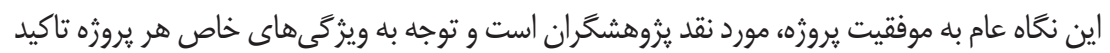
مىشود (Crawford et al., 2005; Shenhar, 2001; Shenhar et al., 2004; Turner, 2014). اين شكاف در بحث مربوط به ابرطرحهاى منطقه آزاد نيز وجود دارد. زيرا ابرطرحهاى منطقه آزاد

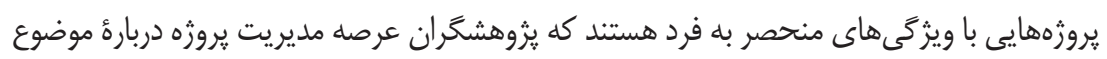
موفقيت آنها كمتوجه بودند. از اينرو، مىتوان نتيجه كرفت كه نياز جدى به به نظريهريردازى در خصوص مولفههاى موفقيت ابرطرحهاى منطقه آزاد و شناسايى عوامل و معيارهاى موفقيت اين خونه

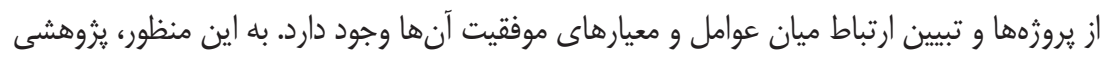

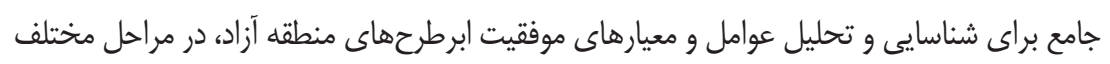

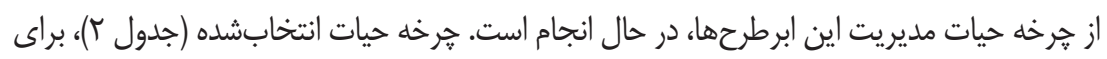
تحليل موفقيت ابرطرح منطقه آزاد داراى هفت مرحله است كه اولين مرحله آن، تعريف ابرطرح منطقه

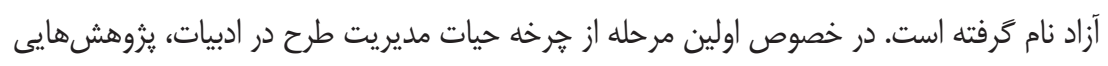

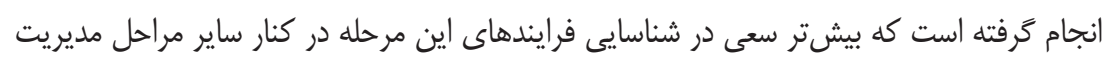

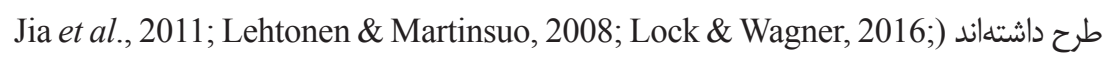
(Lycett et al., 2004; Pellegrinelli, 1997 مرحله تعريف طرح در ادبيات مشاهده نمىشود. يس يثوهش حاضر، بر مرحله تعريف ابرطرح منطقه

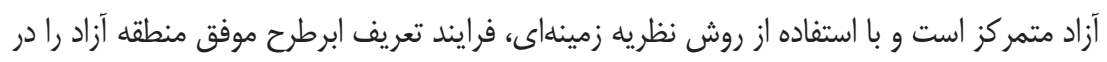
ايران كاوش مى كند. يزوهش حاضر، سعى بر شناسايى عوامل موثر بر تعريف ابرطرح موفق منطقه

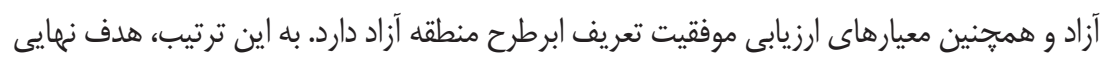
करें

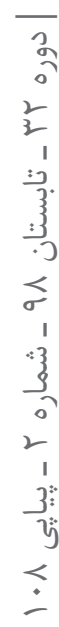
اين يثوهش، تدوين مدل نظرى فرايند تعريف ابرطرح موفق منطقه آزاد در ايران است. همجنين، يرسش هايى كه اين ثيزوهش به آنها ياسخ مى گويد، به اين شرح هستند: نظريه زمينهاى فر ايند تعريف

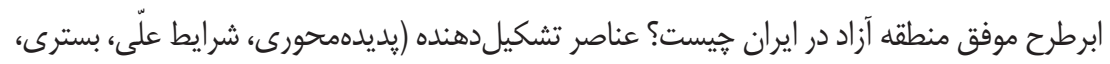
مداخلهَر، راهبردها، و يیامدها) فرايند تعريف ابرطرح موفق منطقه آزاد در ايران كدام هستند؟ و و قضاياى' مستخرج از دادها در خصوص فرايند تعريف ابرطرح موفق منطقه آزاد در ايران كدام هستند؟

1. Propositions 


\section{مبانى نظرى و ويشينة يزووهش}

در اين بخش، تعريفهاى ضرورى و رويكردهاى مختلف به موضوع و مسئله يزوهش، به همراه يِيشينه يزوهش ارائه مىشوند.

\section{ابرطرح منطقه آزاد}

ابرطرح منطقه آزاد، در محدوده معينى از قلمرو يك كشور واقع مىشود و خارج از محدوده

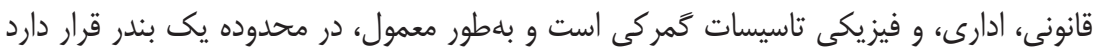

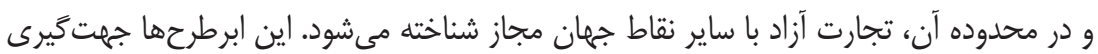

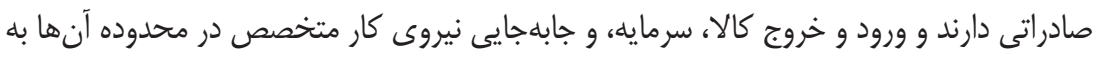

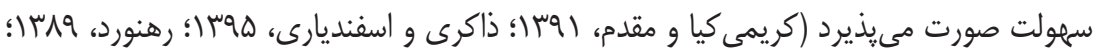

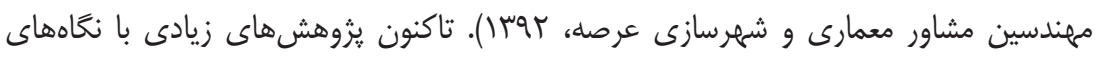

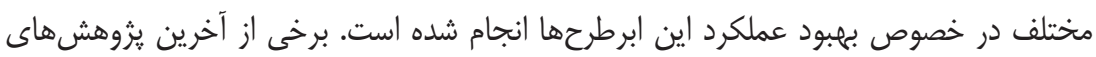

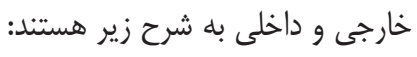

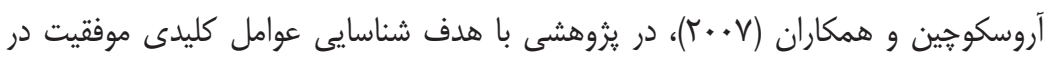

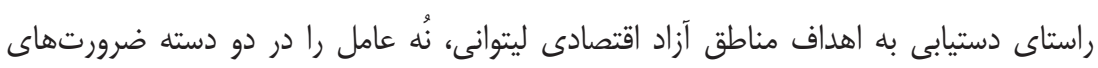

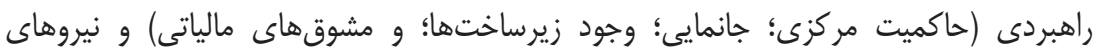

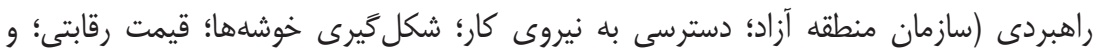

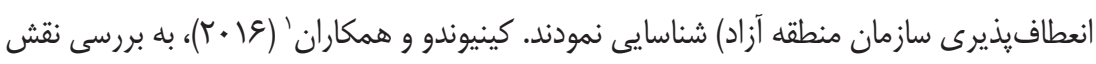

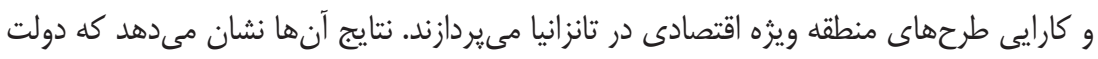

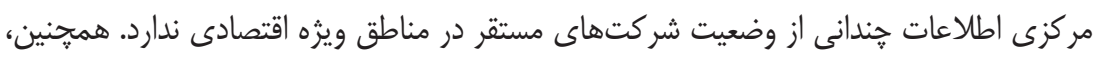

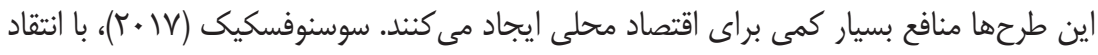

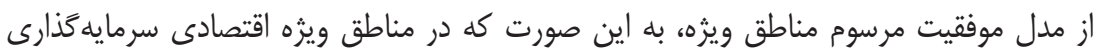

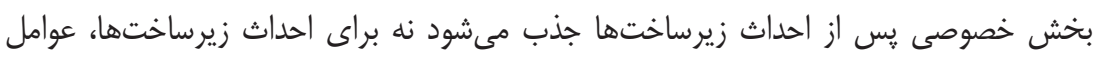

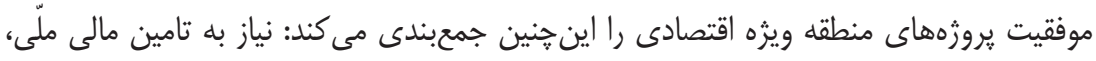

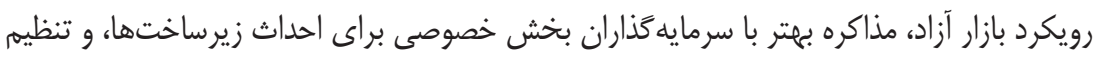

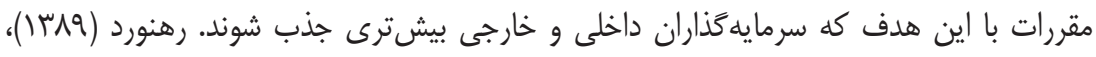

1. Kinyondo et al 
عوامل تاثير گذار بر عملكرد مناطق آزاد ايران را به ينج عامل طبقهبندى مى كند: الزامهاى اجرايى و سياستخذارى؛ عوامل محيطى؛ شفافسازى قوانين و مقررات؛ جهت كيرى راهبردى؛ و سازوكارهاى

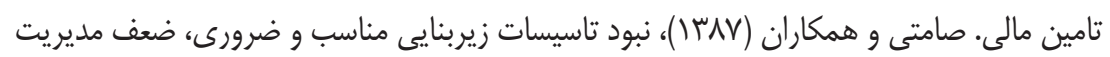

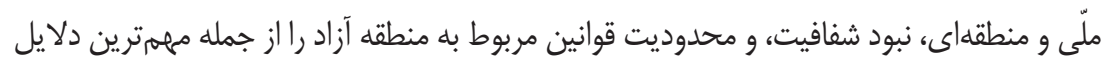
موفق نبودن مناطق آزاد معرفى مى كنئد.

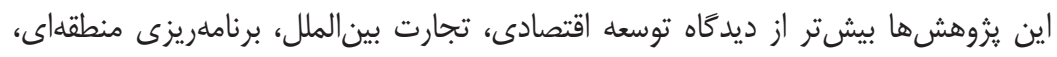

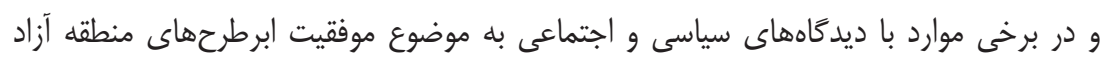

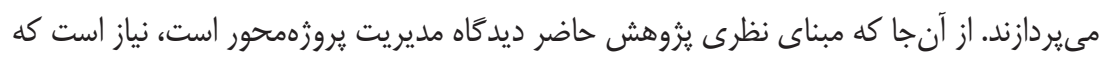
يبشينه موفقيت در مديريت يروزهمحور بررسى شود.

\section{موفقيت ابرطرح منطقه آزاد}

موفقيت يروزه در ادييات داراى دو مولفه اصلى است:

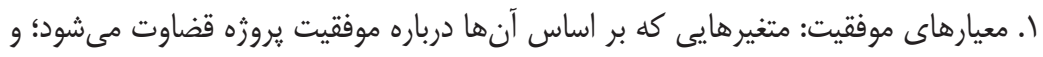

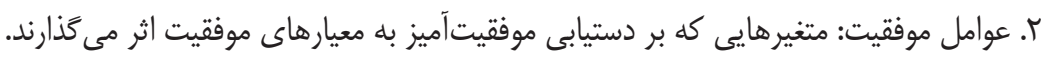

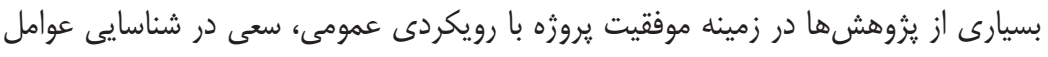

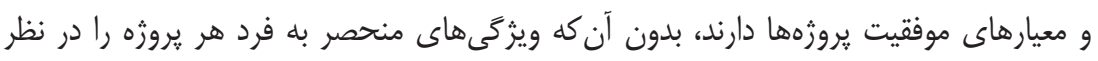

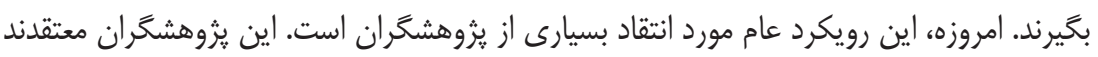

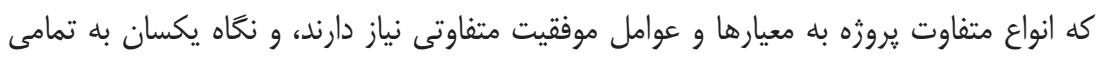

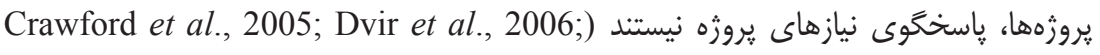
(Shenhar, 2001; Shenhar et al., 2004; Walker \& Rowlinson, 2007 ادامه ويزگ هاى يروزه منطقه آزاد و يزوهش هاى ييشين مرتبط با موفقيت ابرطرحهاى منطقه آزاد

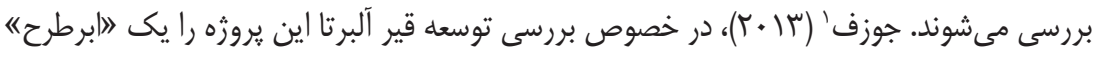

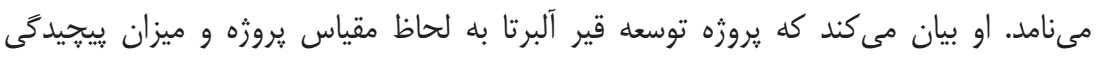

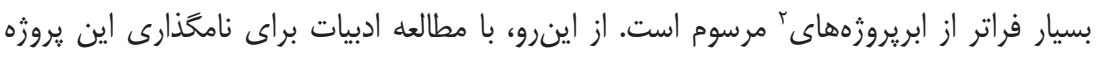

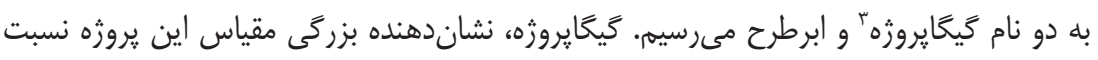

1. Joseph

2. Mega Project

3. Giga Project 
به ابريروزهها و تفاوت كمّى آنهاست. اما ابرطرح، علاوه بر يادآورى مقياس كمّى، نشاندهنده

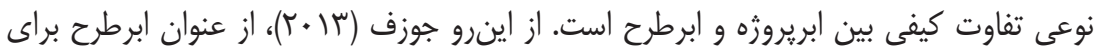

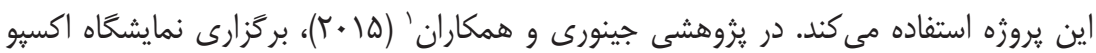

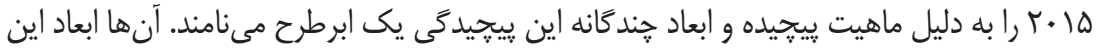
يبيجيدگ

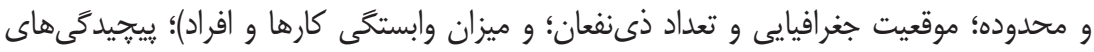

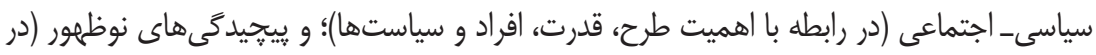
رابطه با ناطمينانى و تغيير كه بلهور معمول نتيجة تازگى فناورى يا فرايندها، كمبود درس آموختهها،

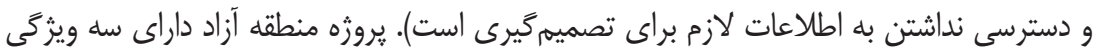

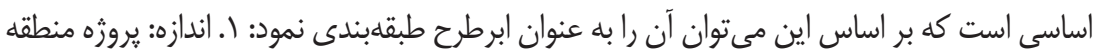

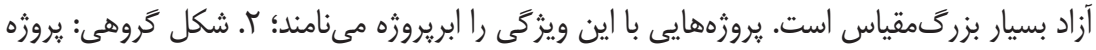

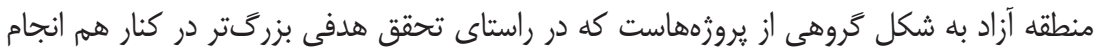

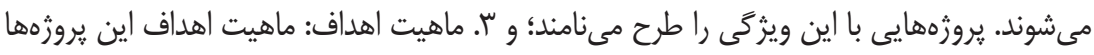
كمتر محصولمحور هستند و بر ايجاد تحول و كسب منافع تاكيد دارند. احرجه تاكنون يثوهشى در زمينه موفقيت ابرطرحها انجام نكَرفته است، اما موفقيت ابريروزهها

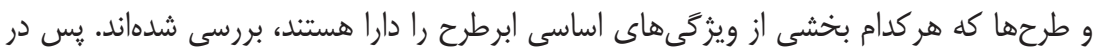

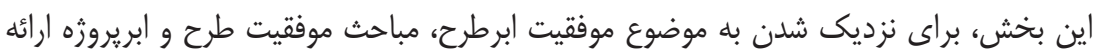

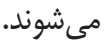

موفقيت طرح: شاوو و همكارانَ (9.+r)، با مرور ادبيات موفقيت طرح به اين نتيجه

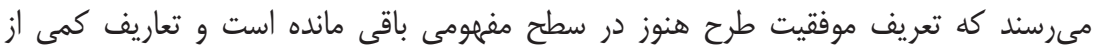

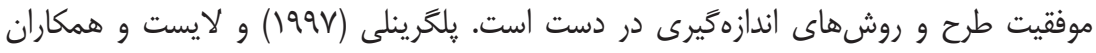

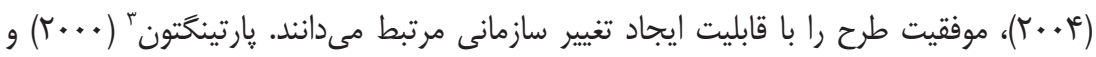

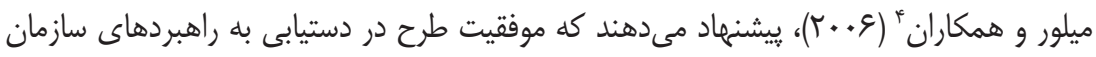

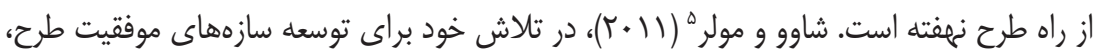

1. Ginevri et al

2. Shao et al

3. Partington

4. Maylor et al

5. Shao \& Müller 
ابعاد شش شانهاى را شناسايى مى كنند. اين ابعاد عبارتاند از راندمان طرح؛ تاثير بر تيم طرح؛

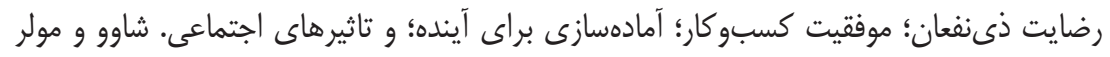

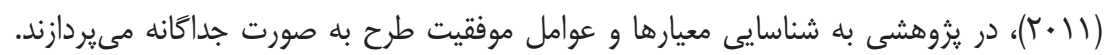
عوامل موفقيت شناسايىشده شامل مدير طرح، مشاركت ذىنفعان، همسويى راهبردى، فرايندها،

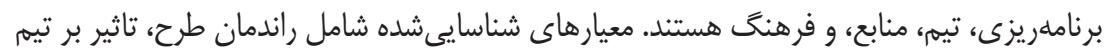

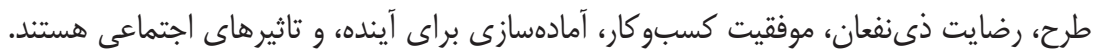

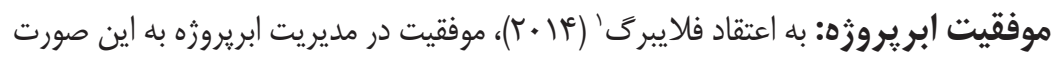

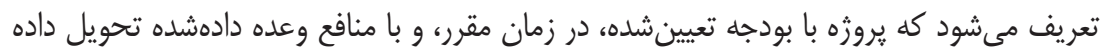

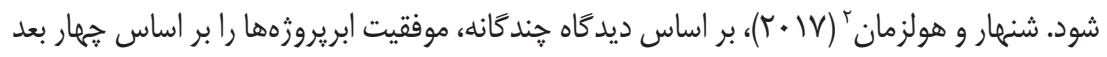

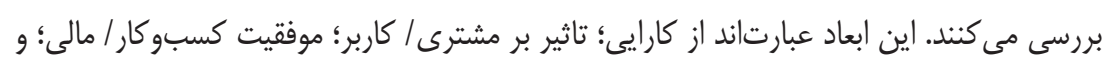

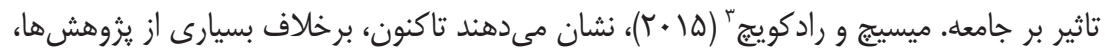

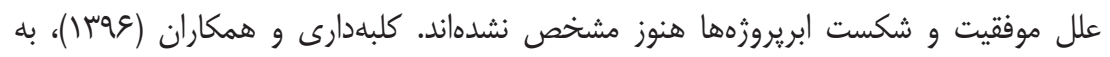

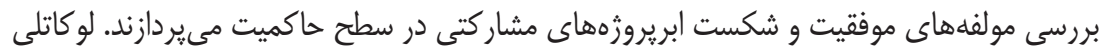

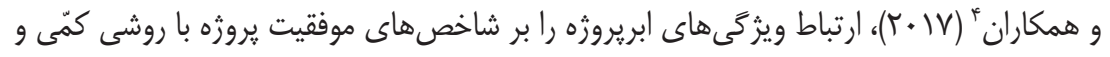
دقيق مشخص مى كنند و مدل عملكرد زمان و هزينه را براى ابريروزهها ارائه مىدهند.

\section{جرخه حيات مديريت طرح}

براى ايجاد نظريه موفقيت ابرطرح منطقه آزاد در ايران، فرايند مديريت ابرطرحهاى منطقه

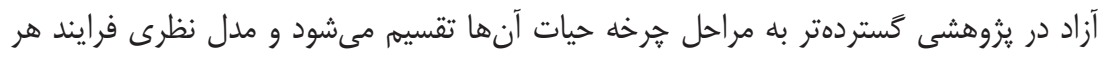

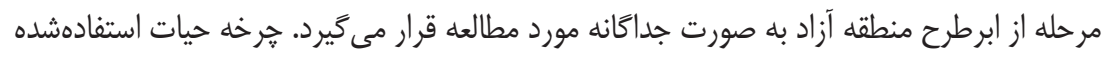
به اين دليل يك جرخه حيات هفت مرحلهاى است كه مبتنى بر هرخه حيات ارائهشده توسط

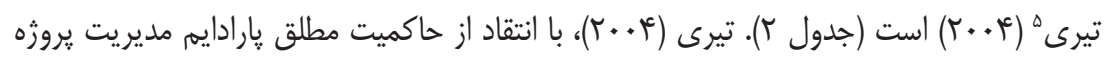

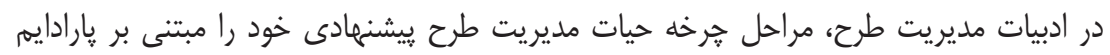

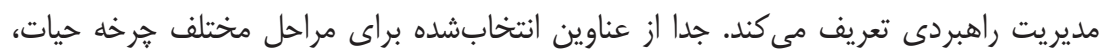

1. Flyvbjerg

2. Shenhar \& Holzmann

3. Mišić \& Radujković

4. Locatelli et al

5. Thiry 


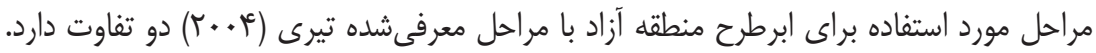

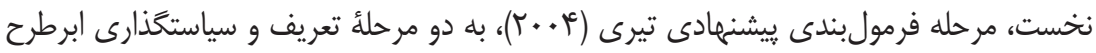

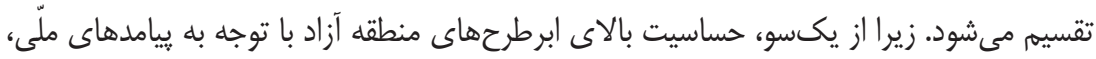

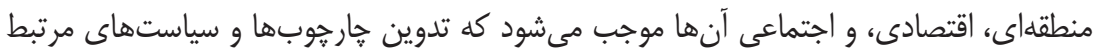

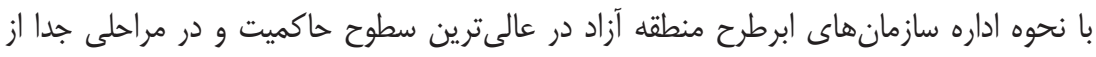
فرايندهاى ابتدايى مديريت طرح انجام گيرد، و از سوى ديگر، ابرطرحهاى منطقه آزاد نياز به

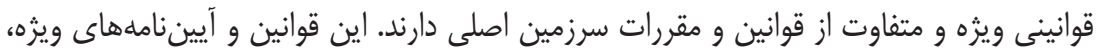

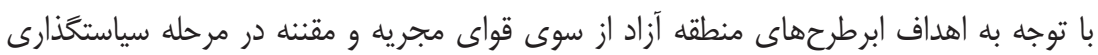

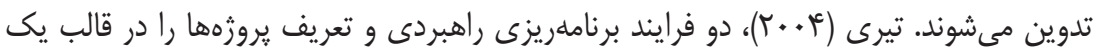
مرحله با عنوان سازماندهى طرح قرار مى دهد. اما به دليل اهميت فرايندهاى برنامهامريزى راهبردى ترى

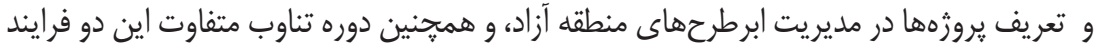

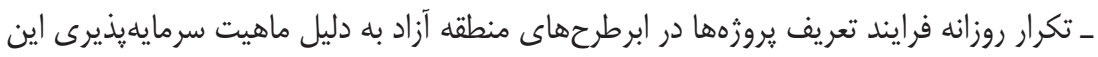

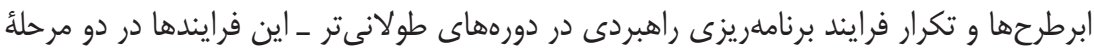

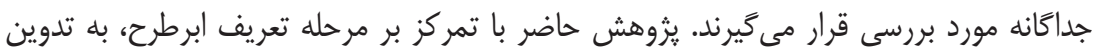

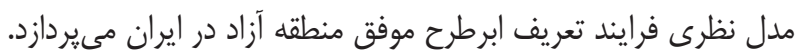

\section{فرايند تعريف طرح در ادبيات}

فرايند تعريف طرح، نخستين مرحله از خرخه حيات مديريت طرح است. با توجه به عناوين

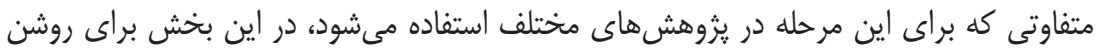

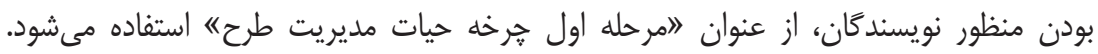

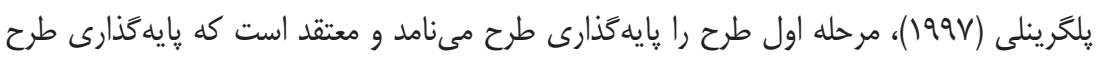

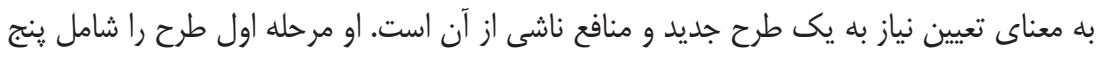

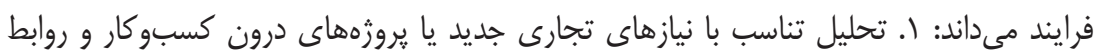

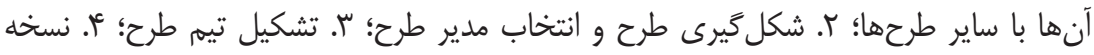

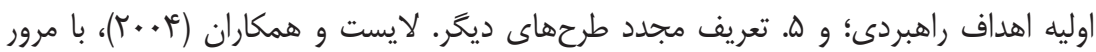

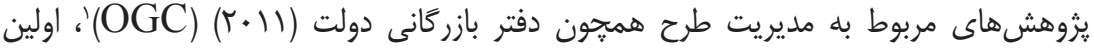

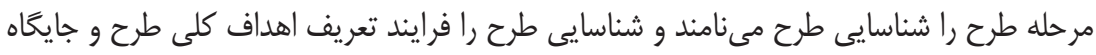

1. Office of Government Commerce 
طرح در ميان ماموريت، آرمانها، راهبردها، و ساير برنامههاى سازمان مىدانند.

جدول ז: مقايسه جرخههاى مختلف حيات مديريت طرح

\begin{tabular}{|c|c|c|c|}
\hline 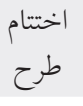 & تحويل منافع طرح & 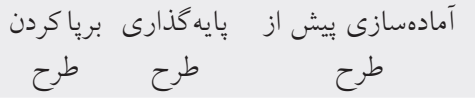 & $\begin{array}{l}\text { Crawford et al. } \\
\qquad \text { (2005) }\end{array}$ \\
\hline 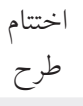 & فازها ت قابليت تحويل منافق تحق & 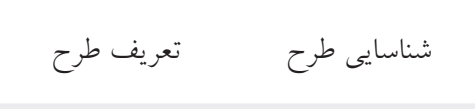 & $\begin{array}{l}\text { Office } \\
\text { (2011) }\end{array}$ \\
\hline اختتام & استقرار & 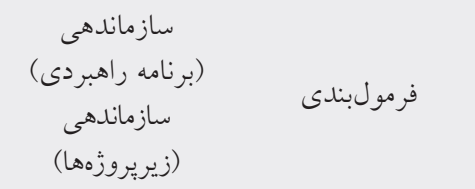 & $\begin{array}{l}\text { Thiry } \\
(2004)\end{array}$ \\
\hline اختتام & ايجاد قابليت منافق & 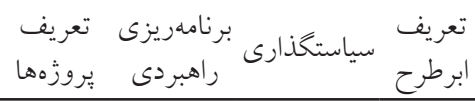 & منطقه آزادح \\
\hline
\end{tabular}

منبع: (Thiry, 2010)

در رويكرد IBMC' ييشنهاد مىشود كه مرحله اول طرح بايد شامل فهرست بهترين يروزههاى ييشنهادى باشد، در حالى كه در رويكرد دفتر بازرگانى دولت (1) (1)، اين فرايند در مرحله دوم

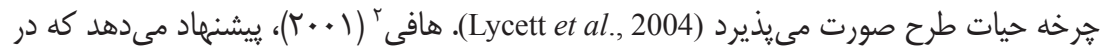
مرحله اول طرح، مرزهاى دقيق محصول طرح توضيح داده شوند. اما لايست و همكاران (أ... (؟)، معتقد هستند كه اين تاكيد بر تعريف دقيق مرزهاى طرح با توجه به ماهيت مبهمم اهداف طرح، تاثير

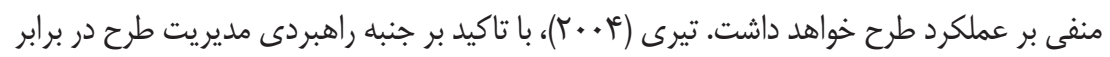
جنبه يروزماى آن، معتقد است كه مرحله اول خرخه حيات مديريت طرح، فرمولبندى طرح است و و هدف اين مرحله، شناسايى فشارهاى بيرونى و درونى براى تغيير و تعيين بهترين مسير براى خلق

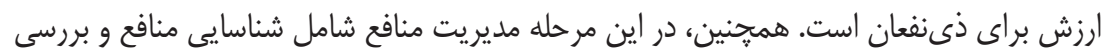

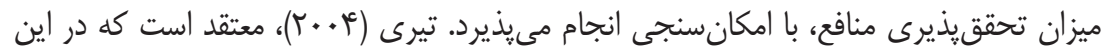

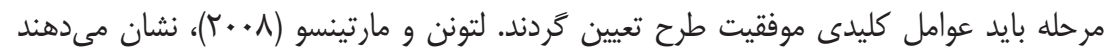

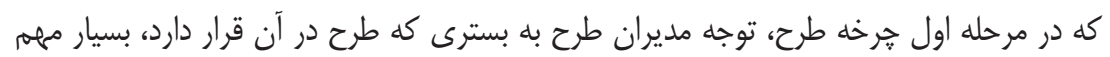
است. جيا و همكاران (1(1) (1)، مرحله ابتدايى ابرطرحهاى صنعت احداث را آمادگى ييش از ابرطرح

1. International Business Machines Corporation

2. Haughey 
مىنامند و فرايندهاى اين مرحله را به اين ترتيب توضيح مىدهند: ا. تمركز بر كارهايى كه بايد

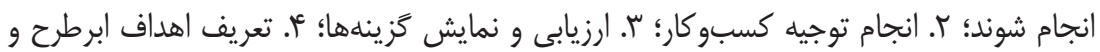

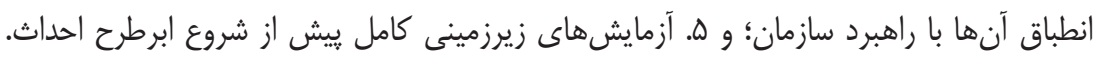

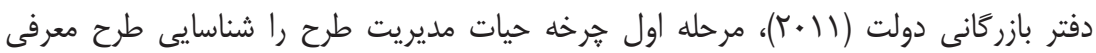

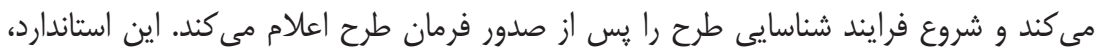

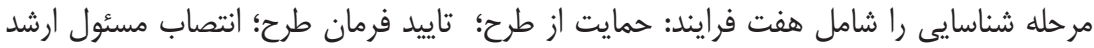

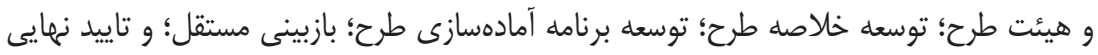

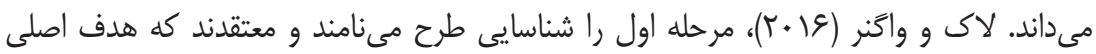

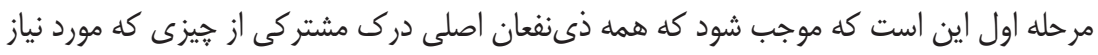

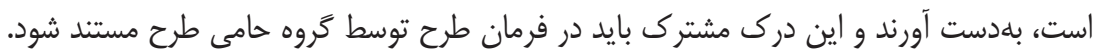

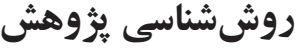

راهبرد مورد استفاده در اين يزوهش، نظريه زمينهاى است. هدف يك يُوهش با راهبرد نظريه

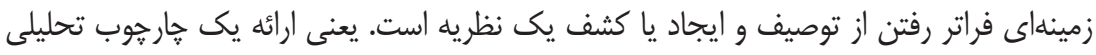

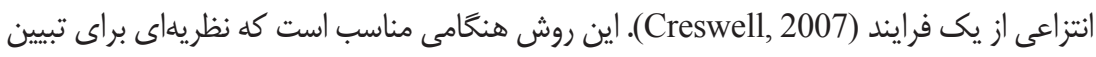
يك فرايند وجود نداشته باشد. با توجه به هدف اين يزوهش كه تدوين مدل نظرى فرايند تعريف

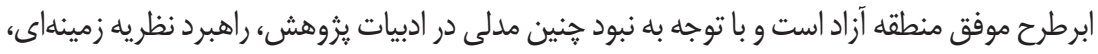

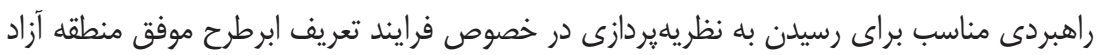

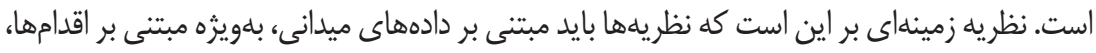

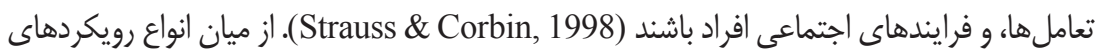

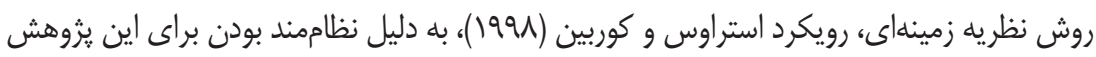
انتخاب مىشود.

در اين يخوهش، با بr نفر از مديران بخش دولتى و خصوصى مرتبط با ابرطرحهاى منطقه آزاد

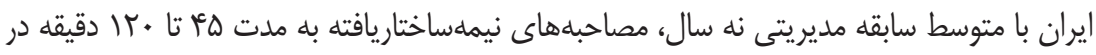

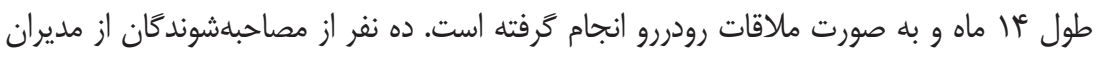

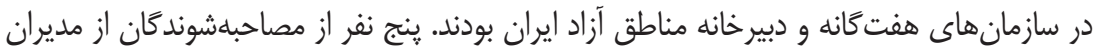

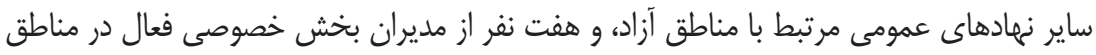

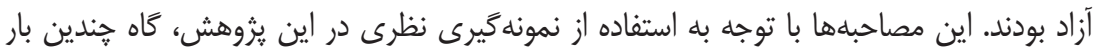


تكرار شدهاند (تكرار برخى مصاحبهها به صورت تلفنى انجام يذيرفته است). در نمونهگيرى نظرى كه روش غالب نمونهگيرى در راهبرد نظريه زمينهاى است، نمونهها به شكلى انتخاب مىشوند كه

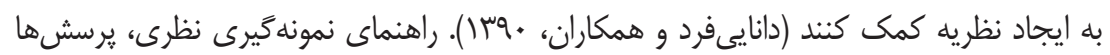
و مقايسههايى هستند كه در خلال تجزيلوتحليل مصاحبهها بروز مىيابند و موجب مىشوند كه مقولههاى مناسب، ابعاد و ويزگى هاى آنها، و ارتباط ميان مقولهها كشف شوند. يعنى در روش نظريه زمينهاى، كدگذارى دادهها همزمان با كَردآورى آنها انجام مى كَيرد (Strauss \& Corbin, 1998). در اين يزوهش، نمونه گيرى نظرى تا رسيدن مقولهها به اشباع نظرى ادامه يافت. مقصود از اشباع نظرى يعنى مرحلهاى كه در آن، دادهاى جديدى در ارتباط با مقوله يديد نيايند و روابط ميان مقولهها برقرار و تاييد شده باشند (دانايىفرد و همكاران، •وس ا). راهبردى كه براى كسب اشباع نظرى در اين يزوهش استفاده مىشود، نمونه گيرى افتراقى است. به اين ترتيب كه دادههاى مازاد از افراد مشابه يا

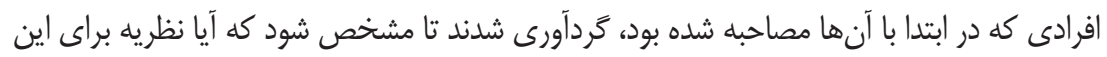
مشاركت كنندكان جديد نيز به قوت خود برقرار است يا خير. در رويكرد استراوس و كوربين (1991)،

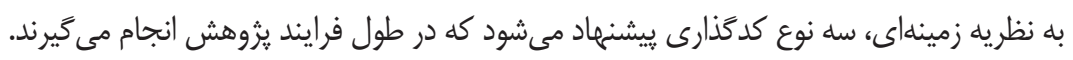

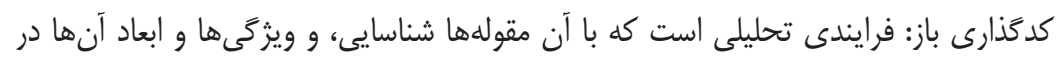

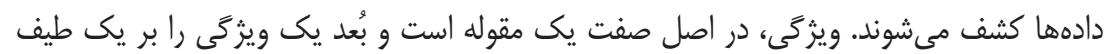
يا ييوستار نشان مى ندهد. كدگذارى محورى: فرايند مرتبط كردن مقوله به زيرمقولهها، كدگذارى محورى ناميده مىشود. علت هنين نامخذارى اين است كه كدگذارى در محور يك مقوله صورت مى گيرد و به وسيله آن، مقوله ها با توجه به ويزگى ها و ابعادشان به مقوله محورى مرتبط مى اسوند.

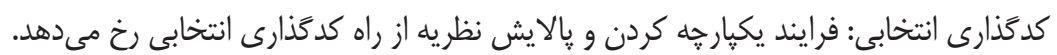

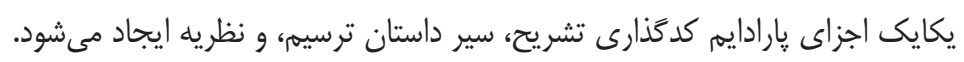
استراوس و كوربين (1991)، براى ارزشيابى ثروهشهایى مبتنى بر نظريه زمينهاى، بلهجاى

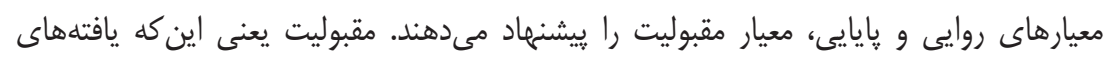

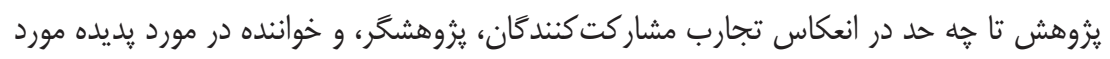
مطالعه، موثق و باوريذير است (Strauss \& Corbin, 1998). به اين منظور، اقدامهاى زير در دراين يزوهش انجام شده است: ا. تطبيق توسط اعضا: مشاركت كنندگان گزارش نهايى يثوهش، فرايند تحليل و مقولههاى بلهدستآمده را بازبينى و نظر خود را در ارتباط با آنها ابراز مى كنند؛ 
r. بررسى همكار: دو تن از دانشجويان دكترى مديريت يروزه و ساخت، به بررسى يافتهها و

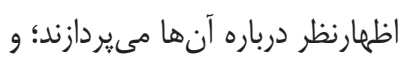

س. مشاركتى بودن يزوهش: بلطور همزمان از مشاركت كنندكان در تحليل و تفسير دادهها

كمك گرفته مىشود.

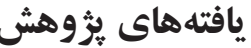

يس از انجام مصاحبههاى نيمهساختاريافته با r نفر از مديران بخش دولتى و خصوصى

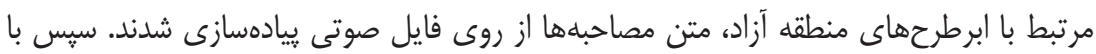

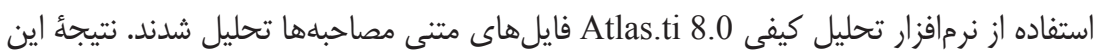

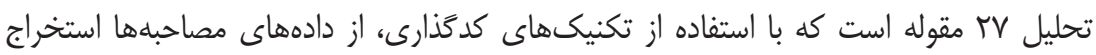
شدند. به اين صورت كه ابتدا با استفاده از تكنيكهاى تحليل خرد (Strauss \& Corbin, 1998)،

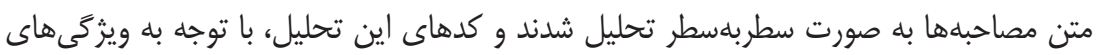

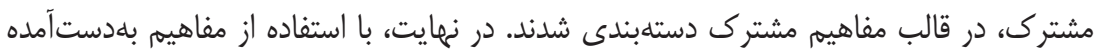

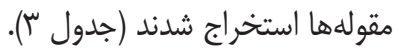

جدول "ז: مقولهها، مفاهيم، و عبارتهاى بهدست آمده از كد كذارى

\begin{tabular}{|c|c|c|}
\hline نمونه عبارت & نمونه مفاهيم & مقوله \\
\hline 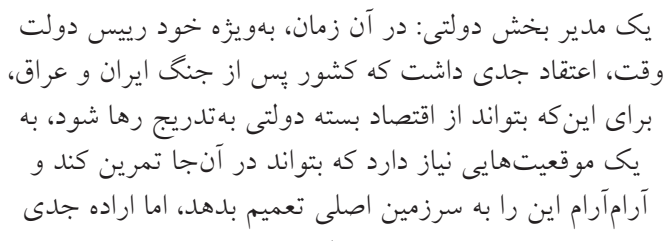 & باور در سطح عالى & باور به ابرطرح \\
\hline 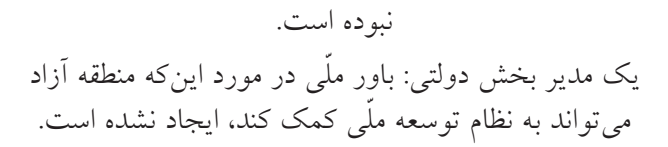 & باور همكانى به مناطق & \\
\hline 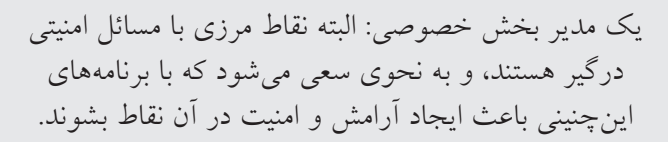 & ناامنى در مرز & امنيت در مرزها \\
\hline
\end{tabular}




\begin{tabular}{|c|c|c|}
\hline نمونه عبارت & نمونه مفاهيم & مقوله \\
\hline 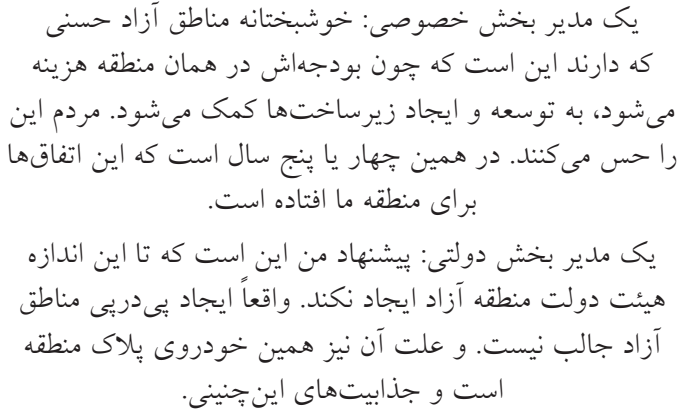 & جابيت هاى & جذابيت ابرطرح \\
\hline 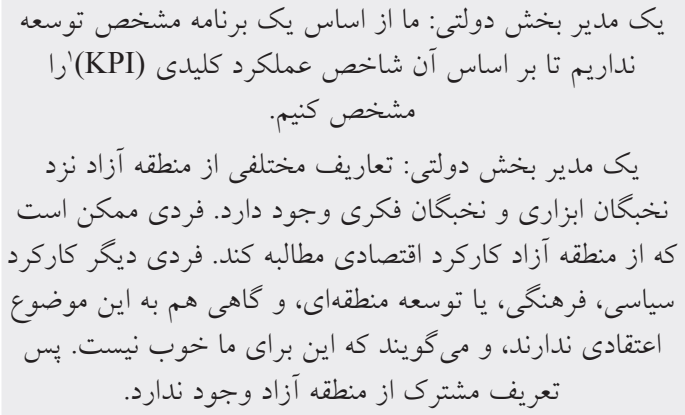 & نخاه مشتر ك & نخرش به كاركرد \\
\hline 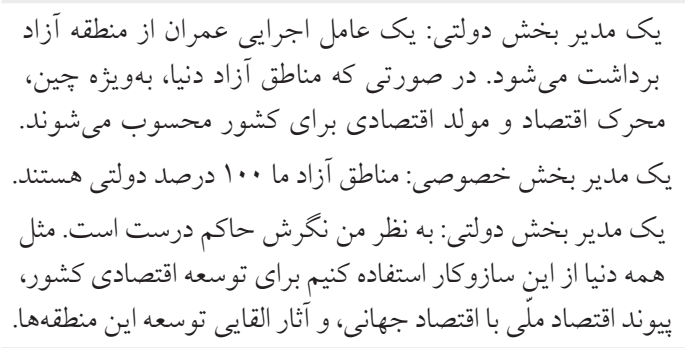 & اقتصاد دولتى & توسعه \\
\hline 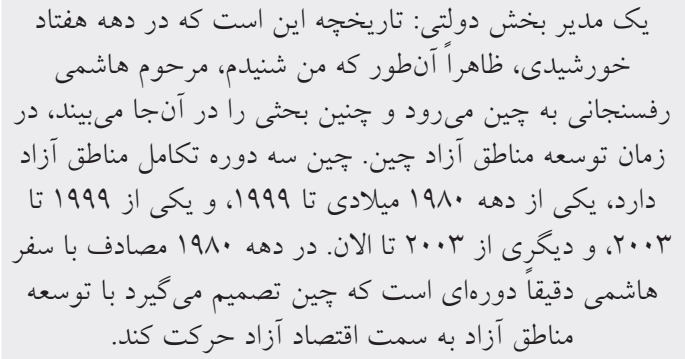 & اقتصاد جهيوند بانى & ارتباط با دنيا \\
\hline
\end{tabular}

1. Key Performance Indicator 


مقوله ل نمونه مفاهيم

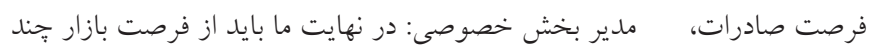
تجارت

فرصتها

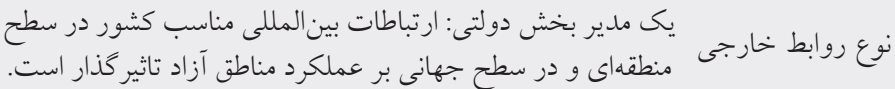

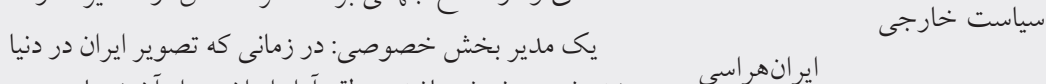

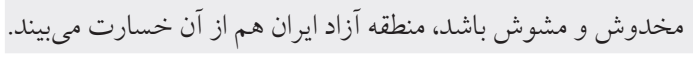
يك مدير بخش دولتى: مباحث اقتصاد كلان، سياست خارجى كلان،

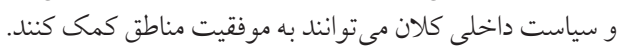

سياست داخلى سياست داخلى ظرفيتهاى قانونى يك مدير بخش خصوصى: يكى از بسترهاى تاثير گذار بر عملكرد

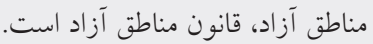

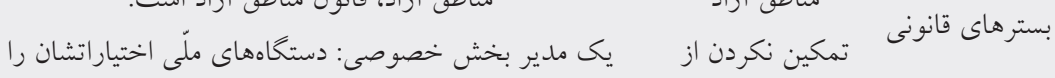
تفويض نكردند. قانون مناطق آزاد

\section{يك مدير بخش دولتى: موقعيت زئويوليتيكى ما.}

جغرافيا ويزّى هاى

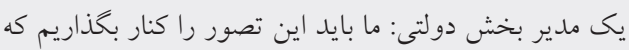

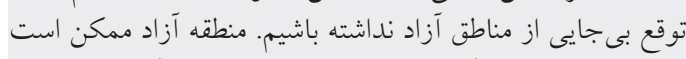

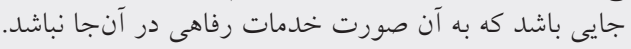

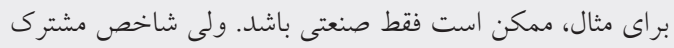
تعريف مناطق آزاد تخصصى تعر اطن امكانسنجى

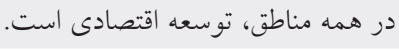

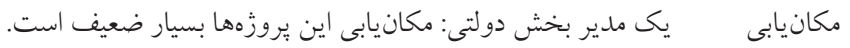

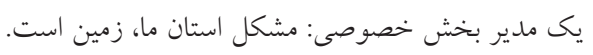

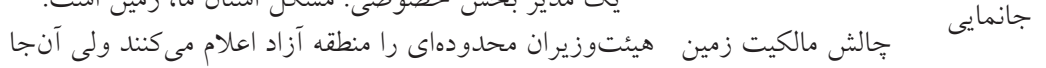

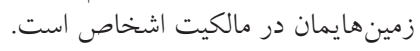

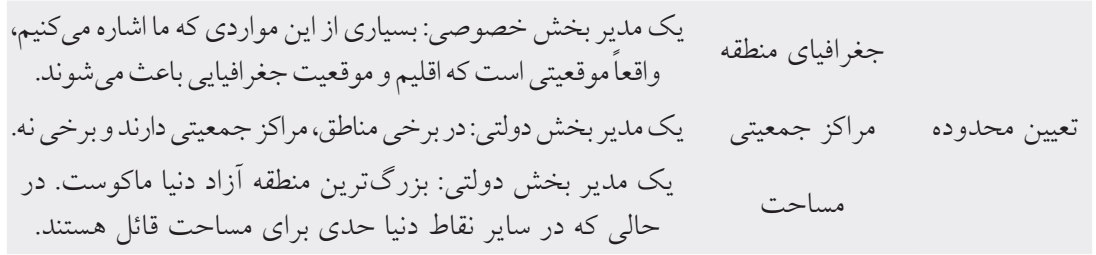

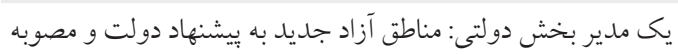

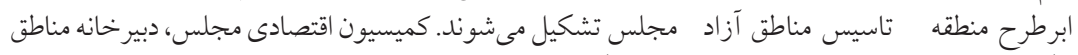

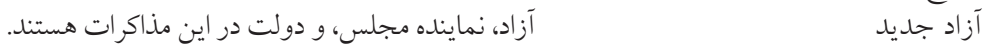

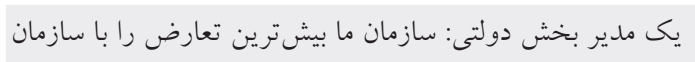

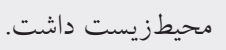




\begin{tabular}{|c|c|c|}
\hline نمونه عبارت & نمونه مفاهيم & مقوله \\
\hline 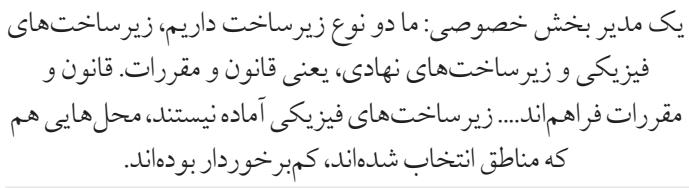 & كمبودزيرساختهاى & زيرساختيت وضات \\
\hline 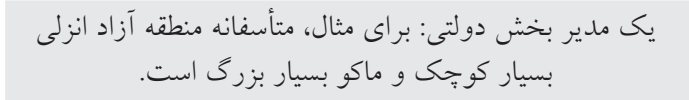 & مسالث & مساحت ابرطرح \\
\hline 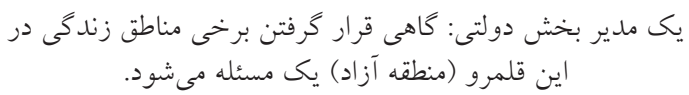 & مراز جالش جمعيتى & تداخل با شهرها \\
\hline 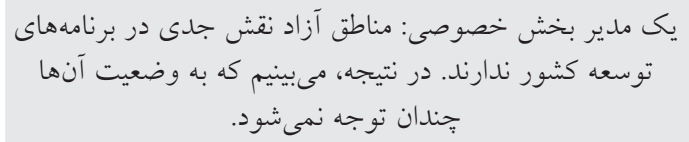 & برنش مناطق در & 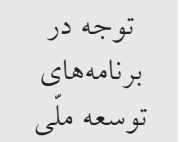 \\
\hline 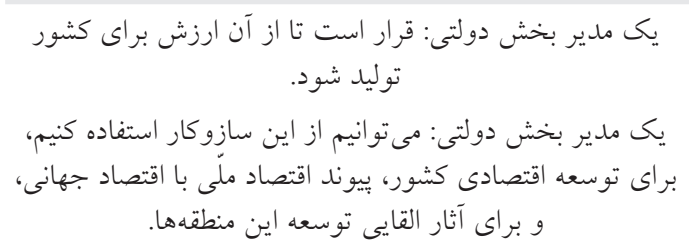 & خلق ارز آينده & جشم انداز \\
\hline يك مدير بخش دولتى: تعداد ذىنفعان مناطق ويثزه كم هستند. & ذىنفعان & ذىنفعان \\
\hline 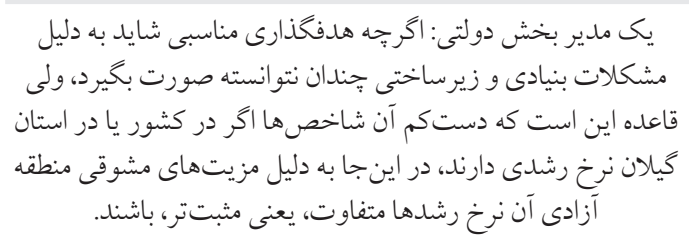 & هدفگذارى & شناسايى اهداف \\
\hline 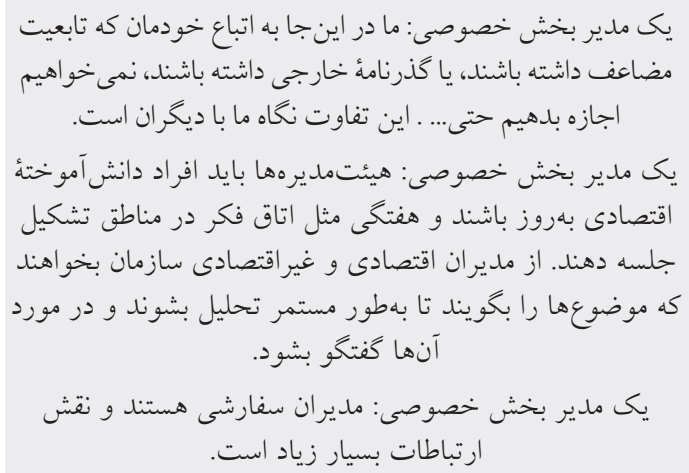 & نغاه در انتخاب & مديريت ابترب تيم \\
\hline
\end{tabular}




\begin{tabular}{|c|c|c|}
\hline نمونه عبارت & نمونه مفاهيم & مقوله \\
\hline 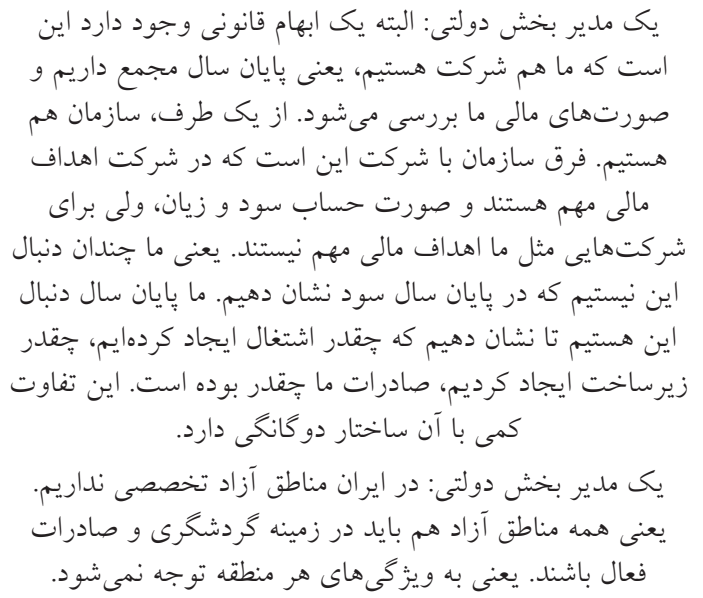 & همتروانى اهداف قانو بانى & اهداف \\
\hline 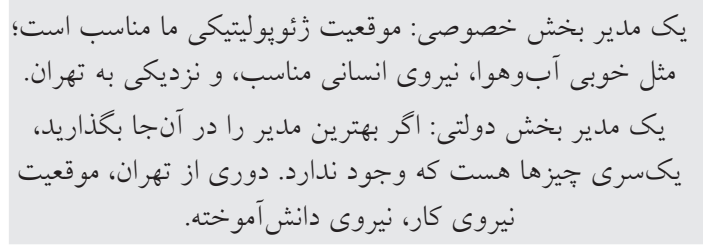 & دسترسى به نيروى متخصص & نيروى انسانى دستى به \\
\hline 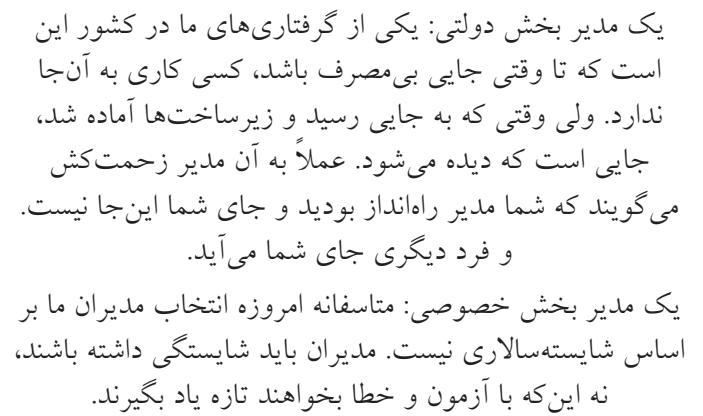 & مديريت كارا & ويزگگى هاى \\
\hline
\end{tabular}

در ادامه فرايند كدگذارى، براى يرورش مقولهها و ويثَى ها، ابعاد مقولهها در دادها شناسايى شدند. همجنين، با استفاده از يارادايم كدگذارى محورى ارتباط ميان مقولهها بر مبناى دادهها شناسايى شدند. در اين بخش، مقولههاى اصلى در شش گروه اصلى ڤيديدهمحورى، شرايط علّى،

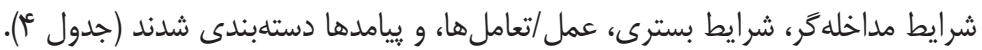


جدول †: ويزگى ها، ابعاد، و نوع ارتباط ميان مقوللهاى يزوهش

مقوله

\begin{tabular}{|c|c|c|c|c|}
\hline 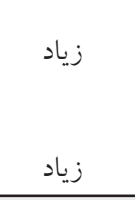 & كم & رويكرد منطقهاى & عزم به تعريف ابرطرح منطقه آزاد & $\begin{array}{l}3 \\
3 \\
3 \\
0 \\
1 \\
1 \\
\text { yे }\end{array}$ \\
\hline زياد & كم & عدالت كر ايى & & \multirow{14}{*}{$\begin{array}{c}\frac{3}{3} \\
\frac{3}{3} \\
\frac{3}{3} \\
\frac{1}{3} \\
\sqrt[3]{3}\end{array}$} \\
\hline سياستزده & توسعه گرا & توسعه كرايى & باور به ابرطرح منطقه آزاد & \\
\hline زياد & كم & انسجام & & \\
\hline 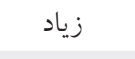 & كم & ميزان & امنيت در مرزها & \\
\hline 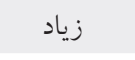 & كم & 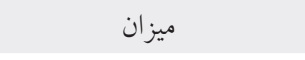 & جذابيت ابرطرح منطقه آزاد & \\
\hline 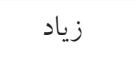 & كم & نغاه سياسى & \multirow{4}{*}{ ابرطرح منطقه كاركرد آزاد } & \\
\hline 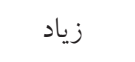 & كم & نغاه امنيتى & & \\
\hline 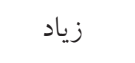 & كم & ن نَاه اقتصاد ملّى & & \\
\hline 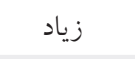 & كم & نخاه محروميتزدايى & & \\
\hline 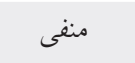 & 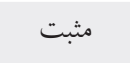 & نخرش & \multirow{3}{*}{ ذى نفعان } & \\
\hline زياد - اد & كم & ت تعداد & & \\
\hline 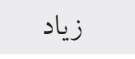 & كم & تنوع نخاهها & & \\
\hline 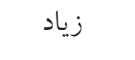 & كم & ميز ان شفافيت & \multirow{2}{*}{ جشم|نداز } & \\
\hline 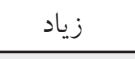 & كم & ميزان تفاهم بر جشم|نداز & & \\
\hline زياد & كم & 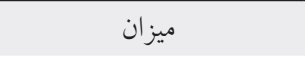 & توسعه يافتكى & \multirow{3}{*}{$\begin{array}{l}\frac{3}{2} \\
\frac{3}{3} \\
\frac{y}{y}\end{array}$} \\
\hline 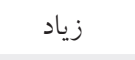 & كم & 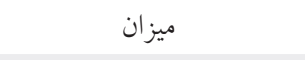 & ارتباط با دنيا & \\
\hline 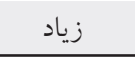 & كم & 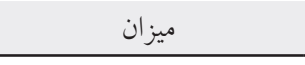 & فرصتها & \\
\hline زياد & كم & ميزان تعامل & سياست خارجى & \multirow{6}{*}{ 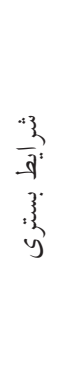 } \\
\hline 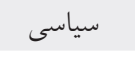 & منطقى & نوع تعامل نهادهاى قدرت & سياست داخلى & \\
\hline زياد - اد & كم & ظرفيت قوانين & \multirow{3}{*}{ بسترهاى قانون } & \\
\hline 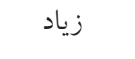 & كم & شفافيت قوانين & & \\
\hline 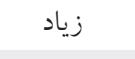 & كم & انعطاف قوانين & & \\
\hline زياد & سخت & حساسيت هاى محيط افياى طبيعى & ويزگ هاى محيطى & \\
\hline
\end{tabular}


ادامه جدول †: ويزگى ها، ابعاد، و نوع ارتباط ميان مقولههاى يخوهش

\begin{tabular}{|c|c|c|c|c|}
\hline \multicolumn{2}{|c|}{ ابعاد } & 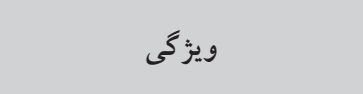 & مقوله & مقوله \\
\hline زياد & كم & دقت مطالعات & امكانسنجى & \multirow{13}{*}{$\begin{array}{l}\frac{3}{3} \\
3 \\
\frac{3}{3} \\
3 \\
3 \\
3 \\
3\end{array}$} \\
\hline زياد - اد & كم & توسعه يافتكى محلى & & \\
\hline 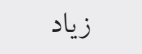 & كم & رقابت هاى سياسى & ح & \\
\hline زياد & كم & فاصله از مركز & 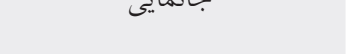 & \\
\hline زياد - اد & كم & فاصله از مبادى مرزى & & \\
\hline 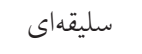 & 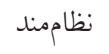 & مبناى تعيين مساحت & & \\
\hline سليقهاى & 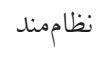 & مبناى تشخيص محدوده & تعــ محلد ده & \\
\hline 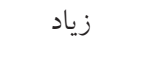 & كم & توجه به محيطزيست & ( & \\
\hline عو امخرايانه & 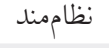 & نوع برخورد با مراكز جمعيتى & & \\
\hline زياد - اد & كم & ميزان تداخل نخاه سياسى & \multirow{3}{*}{ انتخاب تيم مديريت ابرطرح } & \\
\hline زياد & كم & ميزان تداخل نخاه اقتصادى & & \\
\hline زياد - اد & كم & ميزان تداخل نخاه باندى & & \\
\hline اجتماعى زياد & |قتصادى & ميزان مشاركت ذىنفعان & شناسايى اهداف & \\
\hline زياد - اد & كم & انسجام & \multirow{2}{*}{ الهداف } & \multirow{11}{*}{$\frac{3}{3}$} \\
\hline زياد & ك5 & هماهنخى اهداف با بسترهاى قانونى & & \\
\hline 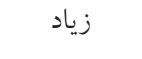 & كم & فيزيكى & \multirow{2}{*}{ وضعيت زير ساختها } & \\
\hline 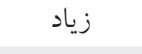 & كم & 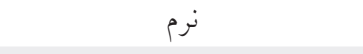 & & \\
\hline زياد & كم & 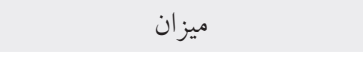 & تداخل با شهرها و روستاها & \\
\hline زياد & 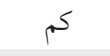 & 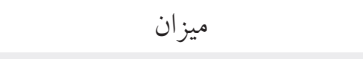 & حساسيت محيطزيستى & \\
\hline 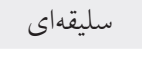 & منطقى & نحوه تعيين & مساحت ابرطرح منطقه آزاد & \\
\hline 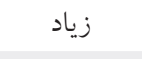 & كم & 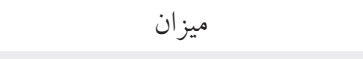 & توجه به برنامههاى توسعه ملّى & \\
\hline 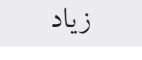 & ك & 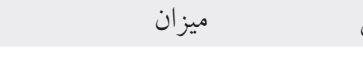 & دسترسى به نيروى انسانى متخصص & \\
\hline 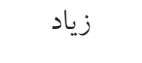 & ك & ميزان سياسى بودن مديران & \multirow{2}{*}{ ويزگكى هاى مديريتى } & \\
\hline تشريفاتى & كارا & هيئتمديرهها & & \\
\hline
\end{tabular}

در مرحله كدگذارى انتخابى، پِ از انتخاب بديده عزم به تعريف ابرطرح منطقه آزاد جديد به عنوان مقوله مركزى، مقولهها به كمك مرتبسازى يادداشتهاى تحليلى و كشف روابط ميان مقولهها، نزديك مقوله مركزى يكبارجهاسازى شدند و داستان تحليلى تدوين شد: 
داستان تحليلى:

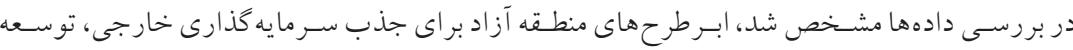

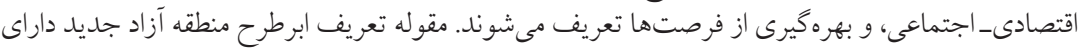

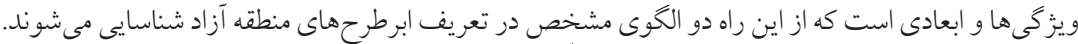

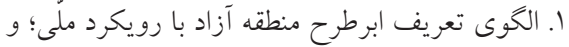

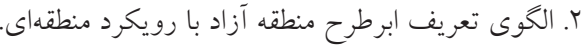

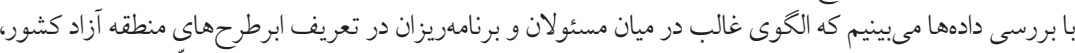

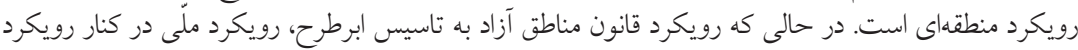

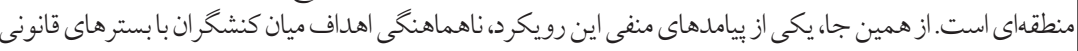

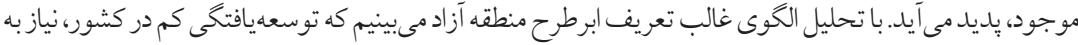

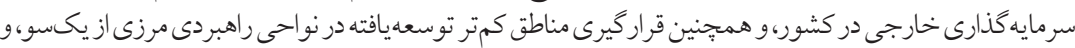

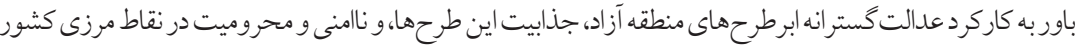

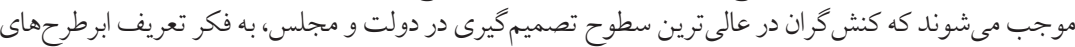

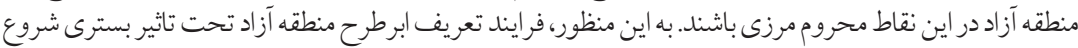

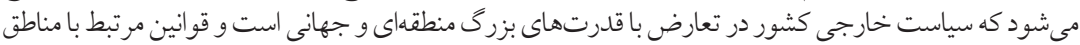

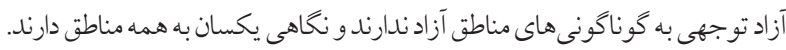

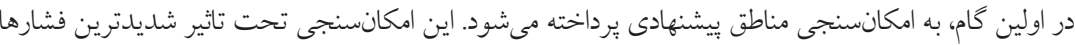

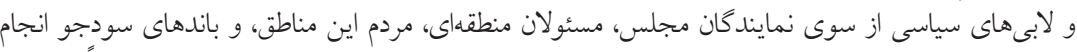

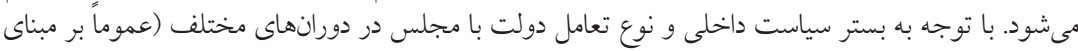

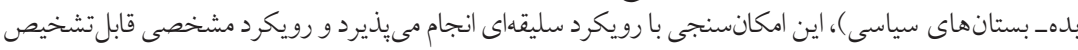

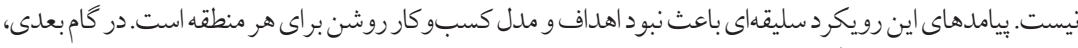

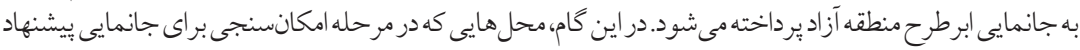

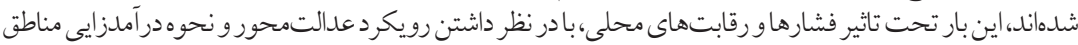

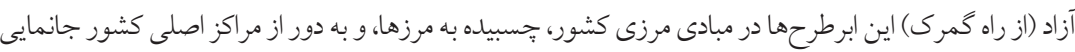

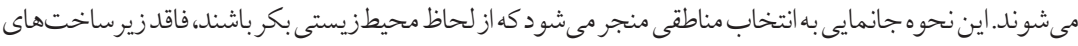

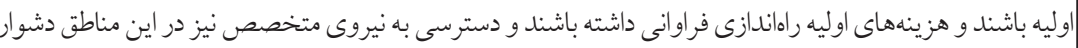

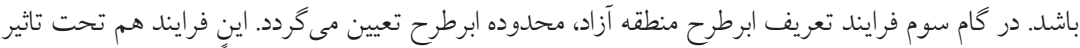

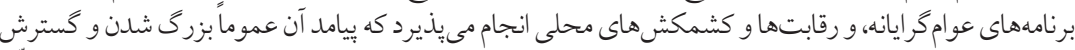

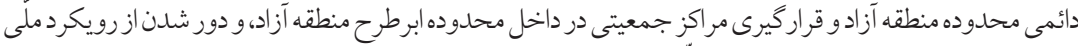

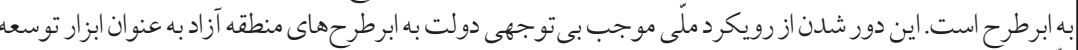

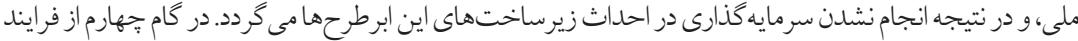

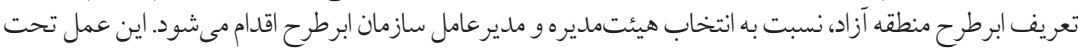

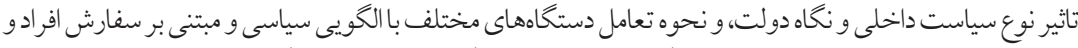

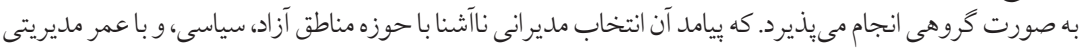

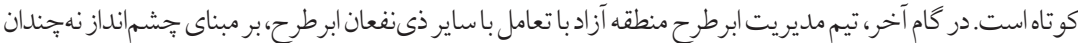

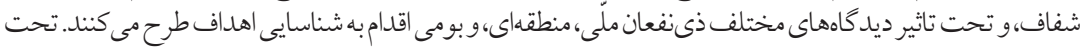

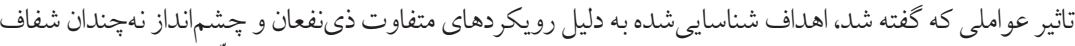

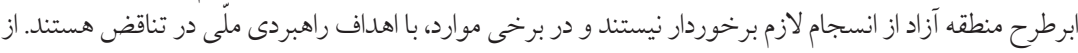

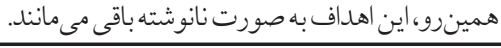


در ادامه، شش قضيه با بهرهيرى از نتايج بهدستآمده از كدگذارى به كمك يافتههاى يثروهش (جدول س و ع) استخراج شدند. اين قضايا به شرح زير هستند:

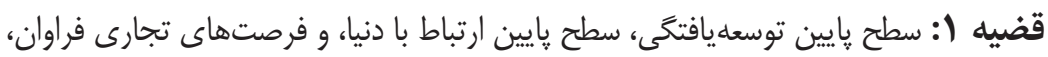

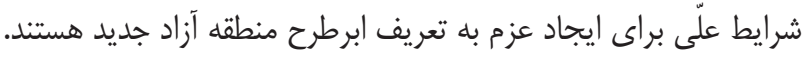

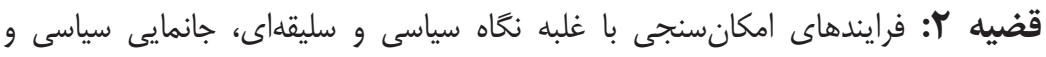
سليقهاى، تعيين محدوده با رويكرد سياسى و سليقهاى، انتخاب تيم مديريت ابرطرح با غلبه نغاه

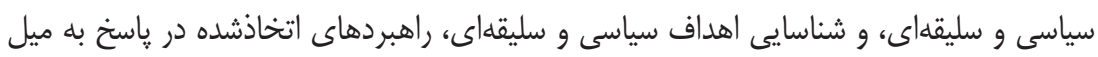

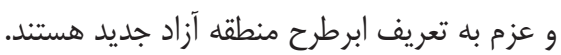

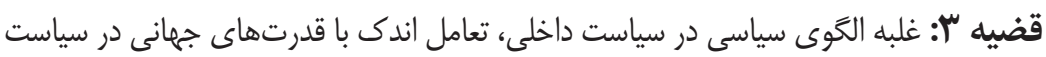

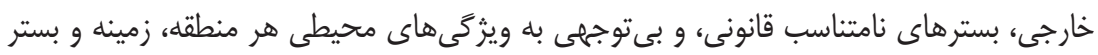

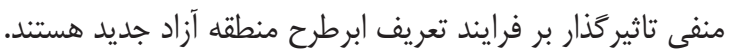
قضيه ع: شرايط مداخله

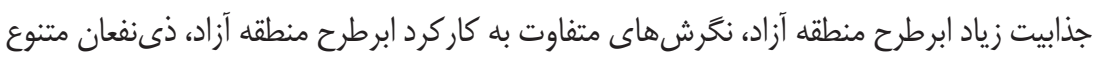

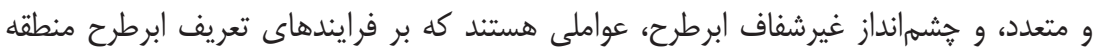
آزاد جديد تاثير مى كذارند. قضيه ه: فرايندهاى امكانسنجى با غلبه نغاه سياسى و سليقهاي، جانمايى سياسى و

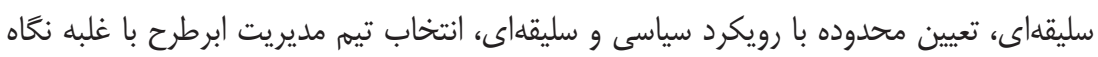

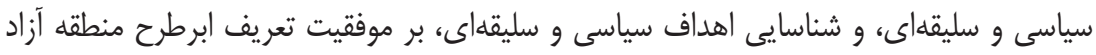
تاثير منفى مى گذارند. قضيه 7 : راهبردهاى اتخاذشده براى تعريف ابرطرح منطقه آزاد، ييامدهاى ميزان كم انسجام

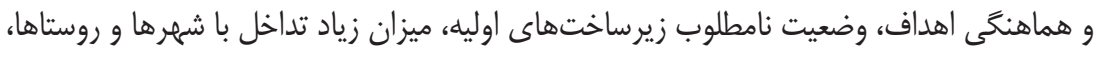

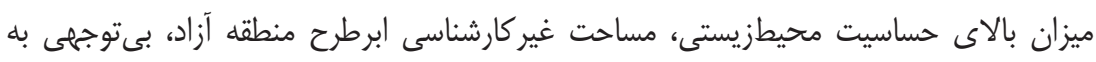

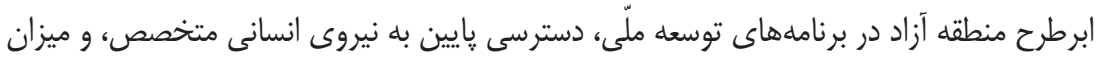
كم كارايى تيه مديريتى ابرطرح منطقه آزاد را به دنبال دارند.

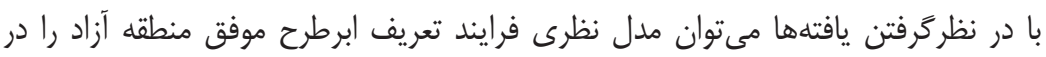




\section{بحث و نتيجه كيرى}

هدف اين يثروشش، تدوين مدل نظرى فرايند تعريف ابرطرح موفق منطقه آزاد در ايران است. اين

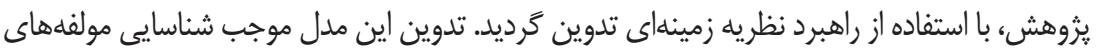

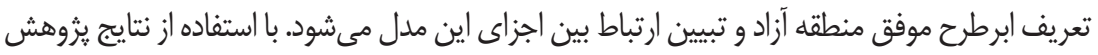

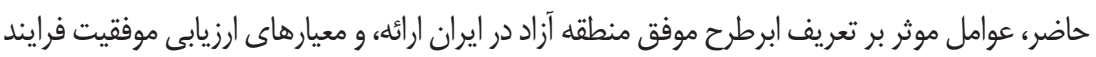

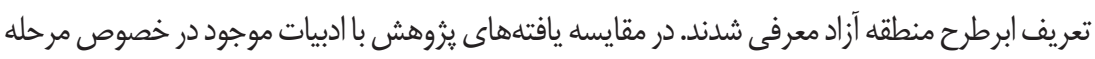
تعريف طرح، مشاهده مىشود كه در مدل نظرى ارائدشده، فرايندهاى شناسايىشده براى تعريف ابرطرح

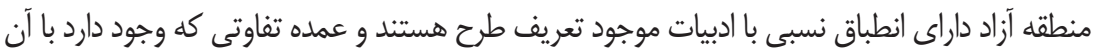

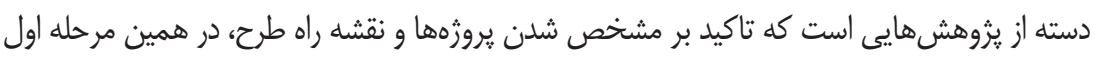

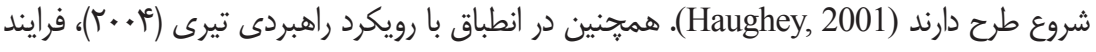

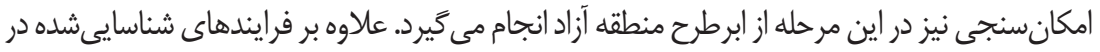

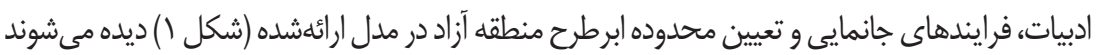
كه نشان دهنده توجه به ويزَّى هاى ابرطرحهاى منطقه آزاد است (Jia et al., 2011). عوامل ديخَرى كه

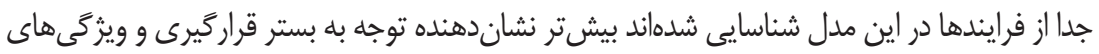

ابرطرحهاى منطقه آزاد ايران هستند (Lehtonen \& Martinsuo, 2008).

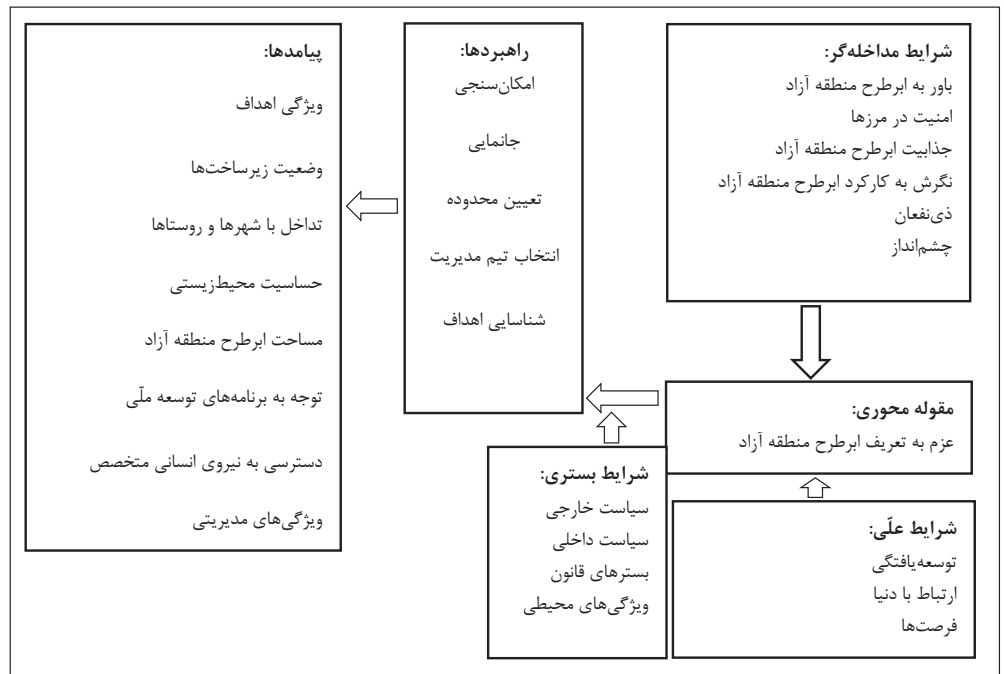

شكل 1: مدل نظرى فرايند تعريف ابرطرح موفق منطقه آزاد در ايران 
مقايسه يافتههاى يثوهش حاضر با يثوهشهايى كه با منظرى متفاوت از مديريت يروزهمحور

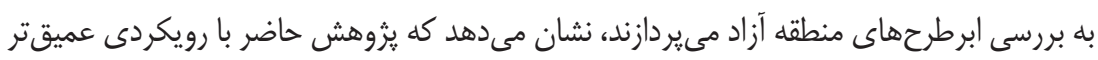

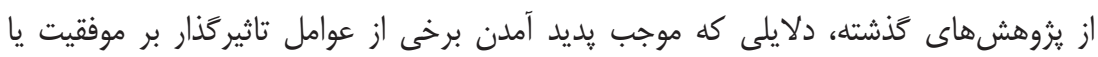

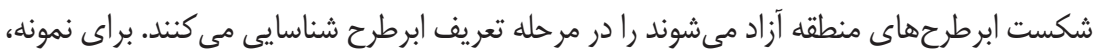

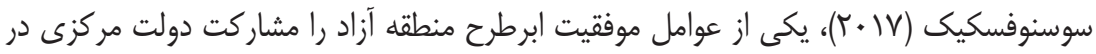

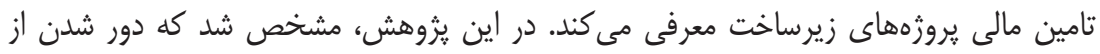

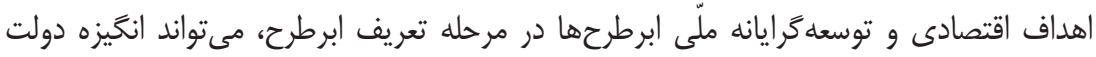

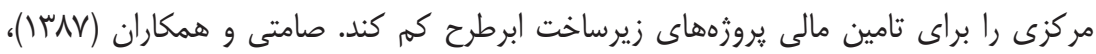

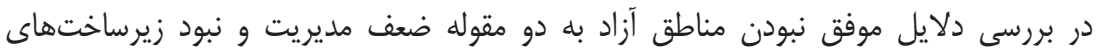

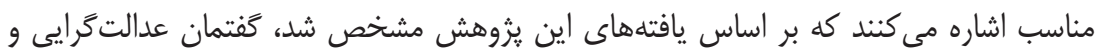

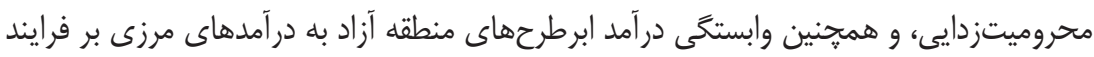

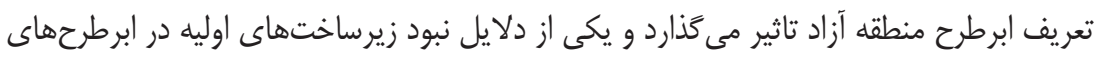

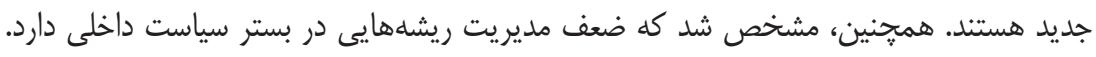

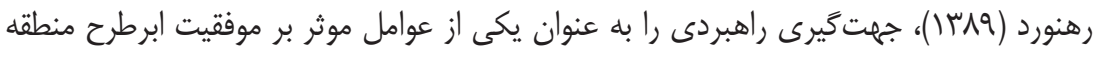

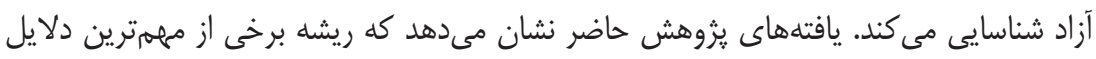

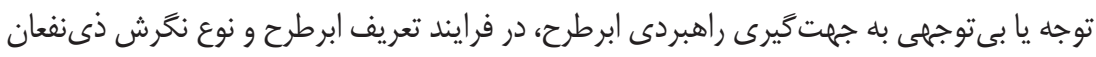
و حاكميت به اين ابرطرحهاست.

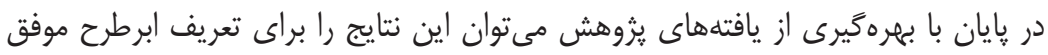

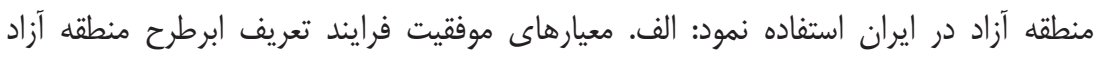

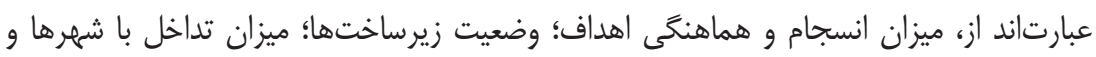

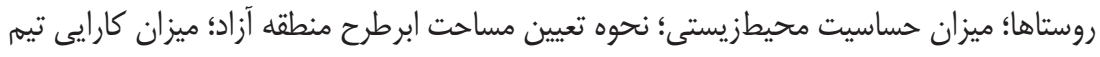

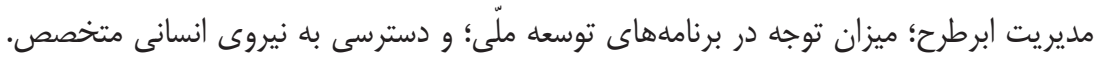

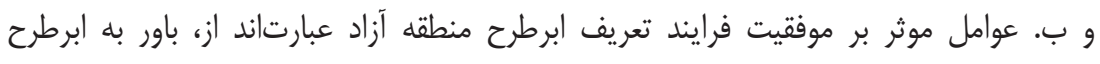

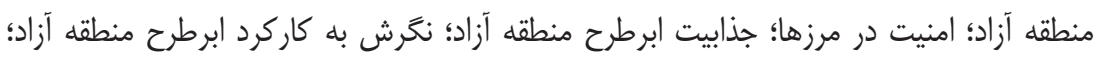

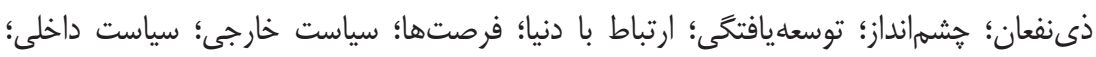

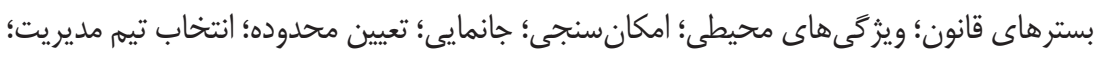
و شناسايى اهداف. با توجه به بررسى نكردن ابرطرحهاى منطقه آزاد از ديدكاه مديريت يروزمهحور، يِيشنهاد 
مى شود كه در بروهشهاى آتى ساير فرايندهاى مربوط به مديريت اين بروزهها از ديدكاه مديريت

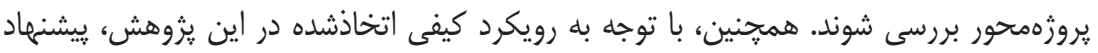

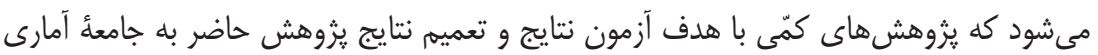

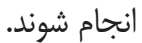

دانايىفرد، حسن؛ الوانى، سيدمهدى، و آذر، عادل (•وس (). روششناسى يُروهش كيفى در مديريت: رويكردى

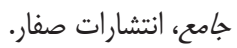

دبيرخانه شوراى عالى مناطق آزاد و ويزه اقتصادى (هوسار). سند راهبردى مناطق آزاداد.

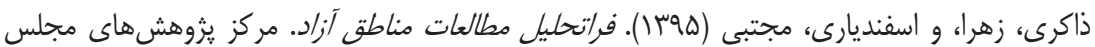

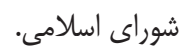
رهنورد، فرجاله (ولى"). عوامل موثر بر عملكرد مناطق آزاد تجارى صنعتى ايران. فرايند مديريت و توسعل، .

صامتى، مجيد؛ بختيارى، صادق، و علىميرزايى، فاطمه (IN (IV). بررسى عملكرد مناطق آزاد ايران. ماهناهه

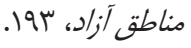

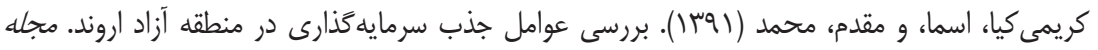

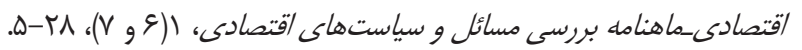

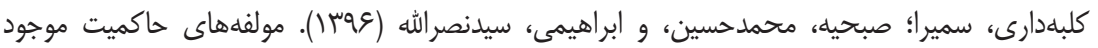

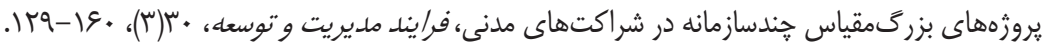

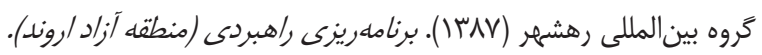

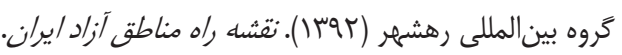

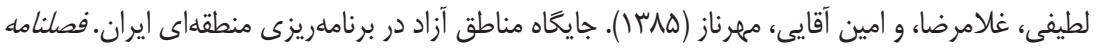

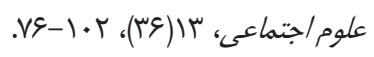

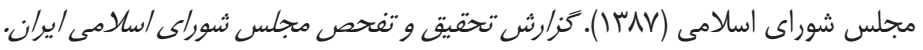

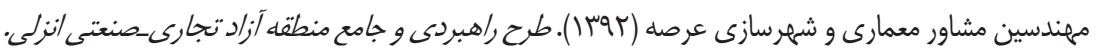

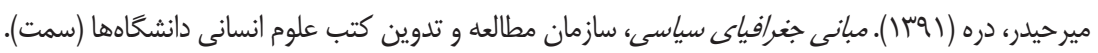


Aggarwal, A. (2010). Economic Impacts of SEZs: Theoretical Approaches and Analysis of Newly Notified SEZs in India. Munich Personal RePEc Archive, 1-60.

Auruškevičienė, V., Šalčiuvienė, L., Kuvykaitė, R., \& Žilys, L. (2007). Identification of Key Success Factors in Free Economic Zone Development in Lithuania. Ekonomika ir Vadyba, 12(1), 277-284.

Bell, T. W. (2016). Special Economic Zones in the United States: From Colonial Charters, to Foreign-Trade Zones, Toward USSEZs. Buffalo Law Review, 64(5), 959-1016.

Cling, J.-P., Razafindrakoto, M., \& Roubaud, F. (2005). Export Processing Zones in Madagascar: A Success Story Under Threat? World Development, 33(5), 785-803.

Crawford, L., Hobbs, B. J., \& Turner, J. R. (2005). Project Categorisation Systems: Project Management Institute.

Creswell, J. W. (2007). Qualitative Inquiry \& Research Design Choosing Among Five Approaches. Sage Publications. Thousand Oaks, CA.

Dvir, D., Sadeh, A., \& Malach-Pines, A. (2006). Projects and Project Managers: The Relationship between Project Managers' Personality, Project Types, and Project Success. Project Management Journal, 37(5), 36-48.

Flyvbjerg, B. (2014). What You Should Know About Megaprojects and Why: An Overview. Project Management Journal, 45(2), 6-19.

Ginevri, W., Acbano, S., \& Institute, P. M. (2015). Mitigating the MultiDimensional Complexity of a Megaprogram: Lessons Learned from EXPO 2015.

Haughey, D. (2001). A Perspective on Programme Management. Project Smart Website.

Jia, G., Chen, Y., Xue, X., Chen, J., Cao, J., \& Tang, K. (2011). Program Management Organization Maturity Integrated Model For Mega Construction Programs in China. International Journal of Project Management, 29(7), 834-845.

Joseph, C. T. R. B. (2013). Megaproject Review in the Megaprogram Context: Examining Alberta Bitumen Development. Environment: School of Resource and Environmental Management.

Kinyondo, A., Newman, C., \& Tarp, F. (2016). The Role and Effectiveness of Special Economic Zones in Tanzania, WIDER Working Paper 2016/122

Lehtonen, P., \& Martinsuo, M. (2008). Change Program Initiation: Defining and Managing the Program-Organization Boundary. International 
Journal of Project Management, 26(1), 21-29.

Locatelli, G., Mikic, M., Kovacevic, M., Brookes, N., \& Ivanisevic, N. (2017).

The Successful Delivery of Megaprojects: A Novel Research Method. Project Management Journal, 48(5), 78-94.

Lock, D., \& Wagner, R. (2016). Gower Handbook of Programme Management: Routledge.

Lycett, M., Rassau, A., \& Danson, J. (2004). Programme Management: A Critical Review. International Journal of Project Management, 22(4), 289-299.

Maylor, H., Brady, T., Cooke-Davies, T., \& Hodgson, D. (2006). From Projectification to Programmification. International Journal of Project Management, 24(8), 663-674.

Mišić, S., \& Radujković, M. (2015). Critical Drivers of Megaprojects Success and Failure. Procedia Engineering, 122(1), 71-80.

Office, S. (2011). Managing Successful Programmes: Stationery Office.

Partington, D. (2000). Implementing Strategy through Programmes of Projects. Gower Handbook of Project Management. Gower Publishing, Aldershot, UK, 33-46.

Pellegrinelli, S. (1997). Programme Management: Organising Project-Based Change. International Journal of Project Management, 15(3), 141-149.

Shao, J., \& Müller, R. (2011). The Development of Constructs of Program Context and Program Success: A Qualitative Study. International Journal of Project Management, 29(8), 947-959.

Shao, J., Turner, R., \& Müller, R. (2009). The Program Manager's Leadership Style and Program Success: A Literature Review and Research Outline. Paper Presented at the Proceedings of IRNOP IX Research Conference.

Shenhar, A., \& Holzmann, V. (2017). The Three Secrets of Megaproject Success: Clear Strategic Vision, Total Alignment, and Adapting to Complexity. Project Management Journal, 48(6), 29-46

Shenhar, A. J. (2001). One Size Does Not Fit All Projects: Exploring Classical Contingency Domains. Management Science, 47(3), 394-414

Shenhar, A. J., Dvir, D., Morris, P., \& Pinto, J. (2004). The Wiley Guide to Project, Program, and Portfolio Management: How Projects Differ and What To Do About It: John Wiley \& Sons.

Sosnovskikh, S. (2017). Industrial Clusters in Russia: The Development of Special Economic Zones and Industrial Parks. Russian Journal of Economics, 3(2), 174-199.

Strauss, A., \& Corbin, J. (1998). Basics of Qualitative Research: Procedures and Techniques for Developing Grounded Theory. In: Thousand Oaks, CA: Sage. 
Tantri, M. L. (2015). Fiscal Implications of Special Economic Zones (SEZs) Expansion in India: A Resource Cost Approach. Journal of International Commerce, Economics and Policy, 6(1), 1-27.

Thiry, M. (2004). "For DAD": A Programme Management Life-Cycle Process. International Journal of Project Management, 22(3), 245-252.

Thiry, M. (2010). Program Management: Gower.

Turner, R. (2014). Handbook of Project-Based Management, Fourth Edition: McGraw-Hill Education.

Walker, D. H., \& Rowlinson, S. (2007). Project Types and Their Procurement Needs Procurement Systems (56-93): Routledge.

Zeng, D. Z. (2016). Special Economic Zones: Lessons from the Global Experience. PEDL Synthesis Paper Series, 1(1), 1-9. 